Article

\title{
Spatial and Temporal Patterns of the Extreme Precipitation across the Tibetan Plateau (1986-2015)
}

\author{
Junnan Xiong ${ }^{1,2}{ }^{\oplus}$, Zhiwei Yong ${ }^{3, *}$, Zegen Wang ${ }^{3, *}$, Weiming Cheng ${ }^{1,4} \oplus^{-}$, Yi Li ${ }^{5}$, Hao Zhang ${ }^{2}$, \\ Chongchong $\mathrm{Ye}^{2}$ and Yanmei Yang ${ }^{2}$ \\ 1 State Key Laboratory of Resources and Environmental Information System, Institute of Geographic Sciences \\ and Natural Resources Research, CAS, Beijing 100101, China \\ 2 School of Civil Engineering and Architecture, Southwest Petroleum University, Chengdu 610500, China \\ 3 School of Geoscience and Technology, Southwest Petroleum University, Chengdu 610500, China \\ 4 University of Chinese Academy of Sciences, Beijing 100049, China \\ 5 Aerospace Information Research Institute, CAS, Beijing 100101, China \\ * Correspondence: yongzhiwei100@163.com (Z.Y.); zegen01@126.com (Z.W.); Tel.: + 86-028-83037604 (Z.Y.); \\ +86-028-83037628 (Z.W.)
}

Received: 6 June 2019; Accepted: 12 July 2019; Published: 14 July 2019

check for updates

\begin{abstract}
The Tibetan Plateau is one of the most vulnerable areas to extreme precipitation. In recent decades, water cycles have accelerated, and the temporal and spatial characteristics of extreme precipitation have undergone dramatic changes across the Tibetan Plateau, especially in its various ecosystems. However, there are few studies that considered the variation of extreme precipitation in various ecosystems, and the impact of El Niño-Southern Oscillation (ENSO), and few researchers have made a quantitative analysis between them. In this study, we analyzed the spatial and temporal pattern of 10 extreme precipitation indices across the Tibetan Plateau (including its four main ecosystems: Forest, alpine meadow, alpine steppe, and desert steppe) based on daily precipitation from 76 meteorological stations over the past 30 years. We used the linear least squares method and Pearson correlation coefficient to examine variation magnitudes of 10 extreme precipitation indices and correlation. Temporal pattern indicated that consecutive wet days (CWD) had a slightly decreasing trend (slope $=-0.006)$, consecutive dry days (CDD), simple daily intensity (SDII), and extreme wet day precipitation (R99) displayed significant increasing trends, while the trends of other indices were not significant. For spatial patterns, the increasing trends of nine extreme precipitation indices (excluding CDD) occurred in the southwestern, middle and northern regions of the Tibetan Plateau; decreasing trends were distributed in the southeastern region, while the spatial pattern of CDD showed the opposite distribution. As to the four different ecosystems, the number of moderate precipitation days (R10mm), number of heavy precipitation days (R20mm), wet day precipitation (PRCPTOT), and very wet day precipitation (R95) in forest ecosystems showed decreasing trends, but CDD exhibited a significant increasing trend (slope $=0.625, P<0.05$ ). In the other three ecosystems, all extreme precipitation indices generally exhibited increasing trends, except for CWD in alpine meadow (slope $=-0.001$ ) and desert steppe (slope $=-0.005)$. Furthermore, the crossover wavelet transform indicated that the ENSO had a 4-year resonance cycle with R95, SDII, R20mm, and CWD. These results provided additional evidence that ENSO play an important remote driver for extreme precipitation variation in the Tibetan Plateau.
\end{abstract}

Keywords: extreme precipitation; spatial and temporal patterns; Tibetan Plateau; ecosystems; ENSO

\section{Introduction}

The spatial and temporal patterns of extreme climatic events become more capricious due to accelerated water cycles over the past several decades [1]. The local and regional floods, droughts 
and snowstorms caused by extreme precipitation events, have an adversely effect on ecosystems, agriculture, industry, and socioeconomic development [2,3]. Thus, the occurrences of extreme climate events and their trends have become the focus of most climate change studies. In the global, extreme precipitation probability have shown an increasing trend, and the total amount of extreme precipitation has increased significantly, and also the tropic region has the most extreme precipitation events $[4,5]$. Additionally, they have more areas with significant increasing trends in extreme precipitation amounts, intensity, and frequency than areas with decreasing trends [6]. On the intercontinental scale, the previous studies have illustrated extreme precipitation variations without spatial consistency. Extreme precipitation in North America has shown an upward trend [7], and extreme precipitation in central and western Africa has shown a downward trend [8]. As the same trend of global change, the frequency and intensity of extreme precipitation events tend to increase in China. The total precipitation in China exhibited an upward trend from the 1960s to 1980s, but a downward trend after the 1980s [9]. Regional studies, including the Yangtze River Basin and northeastern China, show the strongest positive trends [10,11], while the strongest negative trends exist in the southeastern Tibet in China [12].

The Tibetan Plateau, with its unique topography and the highest elevation, plays an essential role in global climate change. The extreme climate in the Tibetan Plateau has an important influence on it and its surrounding areas $[13,14]$. As to the high-altitude areas with glaciers and perennial snow cover, the extreme climate events may cause profound consequences. Investigations at European alpine glaciers indicate that cryosphere change is related to extreme temperature, and extreme precipitation in high-altitude regions can aggravate snow damage and cause potential fluvial floods $[15,16]$. The aforesaid findings might make more sense in the Tibetan Plateau. Previous researches showed a significant warming trend $\left(0.36^{\circ} \mathrm{C} /\right.$ decade $)$ in the Tibetan Plateau from 1960 to 2007 [17], which is greater than that for China $\left(0.26^{\circ} \mathrm{C} /\right.$ decade $)$ [18], and much greater than the global average $\left(0.12^{\circ} \mathrm{C} /\right.$ decade $)$ [19] . Also, previous studies have found that there are large regional discrepancies in precipitation on the Tibet Plateau; and increasing trends were observed in most regions, especially in eastern and central areas [20], while the southeastern areas exhibited a decreasing trend [11]. The variation of extreme precipitation will have a significant impact on the ecosystems and economy of Tibetan Plateau. Thus, exploring the spatial and temporal patterns of extreme precipitation in Tibetan Plateau is important.

Although the spatial and temporal patterns of precipitation in local regions of the Tibetan Plateau have been studied, some problems still persist. First, few studies on the extreme precipitation in the Tibet Plateau has paid the attention to the trends in different ecosystems, and have made a quantitative analysis of the variation of extreme precipitation in various ecosystems. The Tibetan Plateau is a typical and representative high-altitude region due to its precipitation impact on the ecosystem [21], and extreme precipitation causes changes in the ecosystem water and carbon cycles, and these affect the hydrological and ecological processes in different ecosystems [3], thus quantitative analysis is needed to evaluate the variation of extreme precipitation in various ecosystems. Second, variations in the large-scale atmospheric circulation pattern are considered to be one of the most important driving factors affecting precipitation [22,23]. For example, El Niño-Southern Oscillation (ENSO) are remote drivers of extreme precipitation variability across the Tibetan Plateau [24]. Most of the previous studies on the impact of the large-scale atmospheric circulation on precipitation in the Tibetan Plateau have only analyzed annual and seasonal precipitation $[25,26]$ but have not considered the correlation between ENSO and extreme precipitation. Therefore, it is necessary to investigate the spatial and temporal pattern of extreme precipitation across the Tibetan Plateau, the variation and magnitude of extreme precipitation in four different ecosystems (including forest, alpine meadow, alpine steppe, and desert steppe), and the correlation between ENSO and extreme precipitation.

This study explored the spatial and temporal patterns of extreme precipitation across the Tibetan Plateau and in its four different ecosystems, as well as the correlation between ENSO and extreme precipitation. This study had two objectives: (1) Through the Pearson correlation coefficient and linear regression, we analyzed the temporal variation of extreme precipitation across the Tibetan Plateau and in its four different ecosystems, and we explored the spatial pattern of extreme precipitation 
by spatial analysis method in ArcGIS10.5; and (2) we measured the correlation between the ENSO and extreme precipitation by using crossover wavelet transform analysis. This study can improve our understanding to extreme precipitation events affected by climate change, which will provide a foundational analysis to further assess and predict extreme precipitation across the Tibetan Plateau.

\section{Materials and Methods}

\subsection{Study Area}

The Tibetan Plateau encompasses a vast and elevated territory, between $73^{\circ} 19^{\prime}-104^{\circ} 47^{\prime} \mathrm{E}$ and $26^{\circ} 00^{\prime}-39^{\circ} 47^{\prime} \mathrm{N}$, which covers an area of 2.5 million $\mathrm{km}^{2}$, and the average elevation is approximately $4500 \mathrm{~m}$. This region experiences various types of climate, ranging from a hot and rainy to a cold and dry climate, as well as a great number of widespread microclimates that are vertically distributed in the plateau alpine [27]. The Yellow River, Yangtze River, Brahmaputra River and other rivers all originate from the Tibetan Plateau, the plateau becomes a "water tower" for hundreds of million people in the surrounding countries [20,28], thus extreme precipitation-related river discharges [29-31] and mountain hazards [32] can adversely influence populations and the socioeconomic development of local regions, and may further affect sustainable development in the downstream region. As the "world's third pole", and as a region minimally affected by human activity, the Tibetan Plateau has fragile vegetation that is sensitive to climate change [33], precipitation especially plays a more important role than temperature in four different ecosystems of the Tibetan Plateau [34]. Furthermore, most of the study area is dominated by alpine steppes and alpine meadows, the alpine steppe is mainly distributed in northern Tibet and the eastern and western ends of Qinghai Province, which covers 0.71 million $\mathrm{km}^{2}$; the alpine meadow is widely distributed widely in Tibet, Sichuan Province and Qinghai Province, with an area of 0.65 million $\mathrm{km}^{2}$ [28]. Furthermore, the forest area mainly occurs in the south and southeast end of the Tibetan Plateau and large areas of bare land, such as desert steppes are found in the northwest (Figure 1) [35].

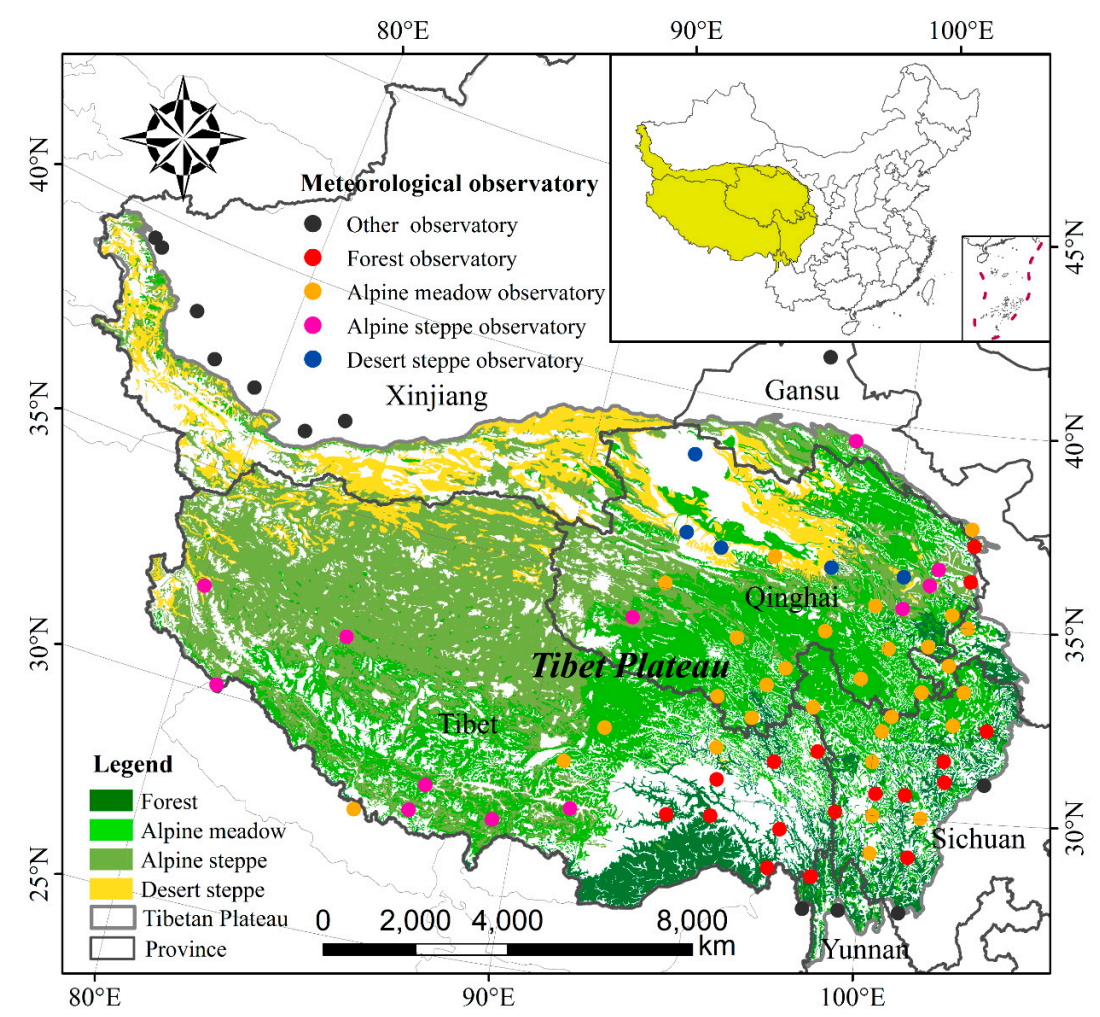

Figure 1. The study area and location of the meteorological stations. The ecosystems covered forest, alpine meadow, alpine steppe, and desert steppe. 


\subsection{Data and Quality Control}

The daily precipitation observational data from 1986 to 2015 used in this study were obtained from the National Meteorological Information Center (http://data.cma.cn/). The World Meteorological Organization have defined a normal climate as being the mean of climatological variables over a 30-year-period [36]. Based on the fact that precipitation data were consecutive and the time series was as long as possible, we collected 76 meteorological observatories around and within the Tibetan Plateau from 1986 to 2015, including other necessary information, such as the World Meteorological Organization number, latitude, longitude, and elevation. Figure 1 shows the location of the meteorological stations within and around the Tibetan Plateau, and the number and average elevation of stations in different ecosystems was showed in Table 1 . To ensure that better data quality was used for this extreme precipitation research, we subjected all the daily precipitation data to strict quality control using the "RClimDex" package and "RHtestsV4" packages (http://cccma.seos.uvic.ca/ETCCDMI) in R software (R Core Development Team, R Foundation for Statistical Computing, Vienna, Austria), which were recommended by the Expert Team on Climate Change Detection and Indices (ETCCDI). The "RClimDex" package was developed by Zhang and Yang et al. [37], which provides a user-friendly program for the calculation of climate extreme indices. Our process was as follows: (1) Replace missing values with -99.9, (2) mark daily precipitation negative data as erroneous data, and (3) check obvious abnormal values of the daily precipitation data. In this paper, abnormal values were defined as daily values exceeding five times standard deviation, and all abnormal values were treated as NA (not available). The abnormal values were identified by examination of visual data graphs. Based on the statistical tests and data from neighboring stations, abnormal values were deleted and corrected. In addition, we assessed the second quality control records for homogeneity to avoid the influence of artificial changes by using "RHtestsV4" software. Based on the penalized maximal F (PMF) test [38], "RHtestsV4" software was capable of identifying step changes in precipitation series by comparing the goodness of fit of a two-phase regression model with that of a linear trend for the entire base series [14,22]. According to the test result of the penalized maximal F (PMF), we found that PMFmax values for each meteorological station were not significant at the 0.05 significance level. Therefore, we selected 76 meteorological stations, because they passed this test in this study.

Table 1. The number and average elevation of stations in different ecosystems.

\begin{tabular}{ccc}
\hline Ecosystem & The Number of Observatory & Average Elevation $(\mathbf{m})$ \\
\hline Forest & 17 & 2919.6 \\
Alpine meadow & 30 & 3629.9 \\
Alpine steppe & 12 & 3517.1 \\
Desert steppe & 5 & 2874.5 \\
Other observatory & 12 & 1678.6 \\
\hline
\end{tabular}

To examine the relationships between extreme precipitation and the large-scale atmospheric circulation patterns, the correlations between the extreme precipitation indices and ENSO indices were investigated. Several indices are available for the representation of ENSO phenomena, such as the Niño 1, Niño 3, Niño 3.4, Southern Oscillation Index, and Multivariate ENSO Index [39]. This study selected the Nino 3.4 index (http://www.esrl.noaa.gov/psd/data/climateindices/list/) to represent the state of ENSO (and the region located between $5^{\circ} \mathrm{N}-5^{\circ} \mathrm{S}$ and $90^{\circ}-150^{\circ} \mathrm{W}$ ), which comprehensively reflected the monthly average sea surface temperature in the eastern central tropical Pacific based on centered 30-year base periods updated every 5-year period [40]. Previous studies had considered that an El Niño event can be said to occur if 5-month running means of sea temperature anomalies in the Niño 3.4 region exceed $0.4{ }^{\circ} \mathrm{C}$ for 6 months or more [41].

The basic geographic data were collected from the Resource and Environment Data Cloud Platform (http://www.resdc.cn/). The basic geographic data included the boundary of the Tibetan Plateau, provincial boundaries, and national boundaries. On the basis of climate, vegetation type and humidity, 
we adopted data using the ecosystems derived from China's vegetation classification system (Chinese Academy of Sciences, 2001) to categorize the Tibetan Plateau into four types: Forest, alpine meadow, alpine steppe, and desert steppe [42].

\subsection{Extreme Precipitation Indices}

Generally, there are various ways to calculate extreme precipitation. ETCCDI has identified 27 types of extreme indices, which include 11 extreme precipitation and 16 extreme temperature (http://etccdi.pacificclimate.org/). This paper selected 10 extreme precipitation indices (Table 2) to reflect the spatial-temporal pattern in extreme precipitation duration, intensity and frequency across the Tibetan Plateau [43]. The 10 extreme precipitation indices reflect many aspects of extreme precipitation with relatively weak extreme, low noise, and strong significance, which have been widely used to analyze the spatial and temporal pattern of extreme precipitation [44]. We divided the 10 indices into precipitation days and precipitation totals. Precipitation days include consecutive dry days (CDD), consecutive wet days (CWD), number of moderate precipitation days (R10mm), and number of heavy precipitation days (R20mm). Precipitation totals include simple daily intensity index (SDII), wet day precipitation (PRCPTOT), maximum 1-day precipitation (RX1day), maximum 5-day precipitation (RX5day), very wet day precipitation (R95), and extremely wet day precipitation (R99) [10,45]. We calculated these indices according to the "RClimDex" package in R software. Table 2 provides a detailed description of these 10 extreme precipitation indices.

Table 2. Indices of extreme precipitation used in this study.

\begin{tabular}{|c|c|c|c|}
\hline Index & Descriptive Name & Definition & Units \\
\hline CDD & Consecutive dry days & Maximum number of consecutive dry days & days \\
\hline CWD & Consecutive wet days & Maximum number of consecutive wet days & days \\
\hline $\mathrm{R} 10 \mathrm{~mm}$ & $\begin{array}{l}\text { Number of moderate } \\
\text { precipitation days }\end{array}$ & Annual count of days when $R R \geq 10 \mathrm{~mm}$ & days \\
\hline $\mathrm{R} 20 \mathrm{~mm}$ & $\begin{array}{l}\text { Number of heavy } \\
\text { precipitation days }\end{array}$ & Annual count of days when $R R \geq 20 \mathrm{~mm}$ & days \\
\hline SDII & Simple daily intensity index & Average precipitation on wet days & $\mathrm{mm} /$ day \\
\hline PRCPTOT & Wet day precipitation & Annual total PRCP in wet days ( $R R \geq 1 \mathrm{~mm})$ & $\mathrm{mm}$ \\
\hline RX1day & $\begin{array}{l}\text { Maximum 1-day } \\
\text { precipitation }\end{array}$ & Annual maximum 1-day precipitation & $\mathrm{mm}$ \\
\hline RX5day & $\begin{array}{l}\text { Maximum 5-day } \\
\text { precipitation }\end{array}$ & $\begin{array}{l}\text { Annual maximum consecutive 5-day } \\
\text { precipitation }\end{array}$ & $\mathrm{mm}$ \\
\hline R95 & Very wet day precipitation & $\begin{array}{l}\text { Annual total precipitation when } \mathrm{RR}>95 \text { th } \\
\text { percentile }\end{array}$ & $\mathrm{mm}$ \\
\hline R99 & $\begin{array}{l}\text { Extremely wet day } \\
\text { precipitation }\end{array}$ & $\begin{array}{l}\text { Annual total precipitation when RR }>99 \text { th } \\
\text { percentile }\end{array}$ & $\mathrm{mm}$ \\
\hline
\end{tabular}

Note: RR is abbreviation for daily precipitation, and a dry (or wet) day is defined as $\mathrm{RR}<1 \mathrm{~mm} /$ day.

\subsection{Data Analysis Methods}

\subsubsection{Spatio-Temporal Analysis Methods}

To analyze the temporal characteristics of extreme precipitation in Tibetan Plateau, the variation trends of the extreme precipitation indices were calculated in this study applying the ordinary least squares regression method in SPSS and Origin 2018 software, as widely applied in extreme climate studies $[9,44,46]$. Additionally, the ordinary least squares regression method can comprehensively reflect the annual trend of extreme precipitation indices. The positive and negative trends were defined using the slope of least squares regression. A slope $>0$ indicates that it is positive trend; a slope $<0$ indicates that it is a negative trend, and a slope $=0$ indicates no trend. The t-test is a popular method in the significance test, which was used to estimate the significant linear trends of extreme precipitation indices at the 0.05 level of confidence [47]. If the $P$ value $<0.05$, it indicates that the linear trends are 
significant. Additionally, we counted the number of stations with similar trends of every extreme precipitation indices and significant variation. Then, we used a five-year smoothing average value to show the variations in extreme precipitation, which was a robust curve fitting method, as widely used to analyze the inter-annual variation in extreme climates $[46,48]$.

We analyzed the spatial patterns of the indices representing extreme precipitation. The Kriging method was employed to interpolate the values into the whole study area by means of the software of ArcGIS 10.5. Detailed information about the method were described by previous researchers [49-51]. In the method, the parameters setting includes the semivariogram model (linear), lag size (12), and the point number of search radius (12).

\subsubsection{Crossover Wavelet Transform}

The wavelet transform has become a useful method to study regional variations of time series data and has been used widely in climatic time series analysis [51,52]. Crossover wavelet transform was introduced by Torrence and Compo in 1998 [53]. Furthermore, the correlation relationship between ENSO and extreme precipitation indices were analyzed by the crossover wavelet transform, and revealed the periodic characteristics of extreme precipitation in different time scales [46]. With two times series $x_{n}$ and $y_{n}$, we can define the crossover wavelet spectrum as follows:

$$
W_{n}^{x y}=W_{n}^{x} W_{n}^{y *}
$$

where $W_{n}{ }^{x}$ and $W_{n}{ }^{y}$ denotes the wavelet transforms and * represents the complex conjugate. In addition, the cross wavelet power is further defined as $\left|W_{n}{ }^{x y}\right|$. The complex $\operatorname{argument} \arg \left(W_{n}{ }^{x y}\right)$ can be interpreted as the local relative phase between $x_{n}$ and $y_{n}$ in time frequency space [49].

The theoretical distribution of the crossover wavelet power of $x_{n}$ and $y_{n}$ with background power spectra $P_{n}^{x}$ and $P_{n}^{y}$ is given as follows:

$$
D\left(\frac{\left|W_{n}^{x}(S) W_{n}^{y *}(S)\right|}{\sigma_{x} \sigma_{y}}<p\right)=\frac{Z_{v}(p)}{v} \sqrt{P_{n}^{x} P_{n}^{y}}
$$

where $Z_{v}(p)$ is the confidence level associated with the probability density function $p$, which is defined by the square root of the product of two $\chi^{2}$ distributions. In this study, the 0.05 significance level can be calculated by means of $Z_{2}(0.95)=3.999$.

\section{Results}

\subsection{Temporal Trends of Precipitation Extremes Indices}

\subsubsection{Temporal Trends of Precipitation Days}

Figure 2 shown regional annual series and linear trends of precipitation days indices across the Tibetan Plateau. During 1986-2015, CDD experienced an increasing trend at a rate of 0.43 day/year, fluctuating between 66.97 and 105.23 days, and the maximum and minimum values appeared in 1986 and 2010, respectively (Figure 2a). CWD showed a slightly decreasing trend at a rate of 0.006 day/year, and the fluctuation of index was intense before 2000 (ranged from 5.969 to 8.391 days) but then slowed down (Figure 2b). By contrast, R10mm and R20mm showed similar trends ( 0.023 and 0.003 day/year, respectively), but their trends did not pass the 0.05 significance test (Figure 2c,d). 


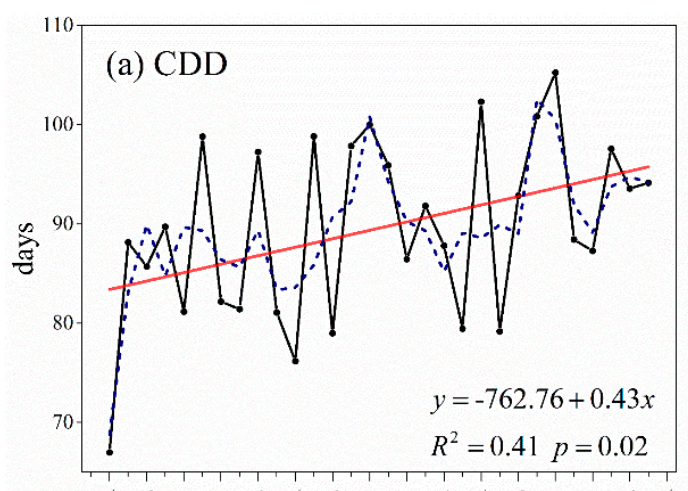

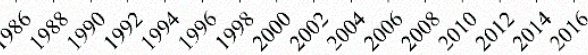

Year

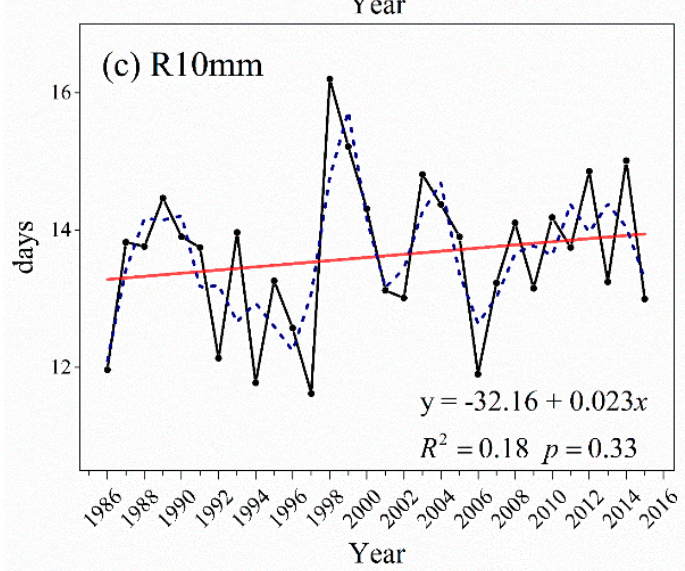

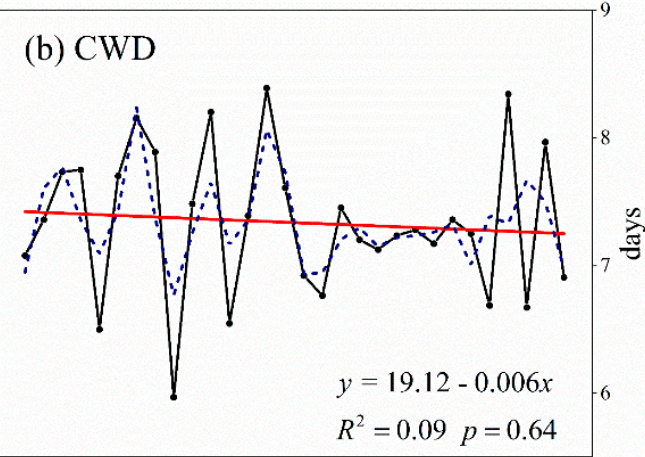

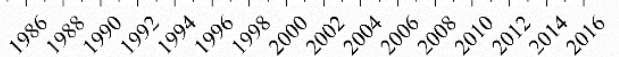
Year

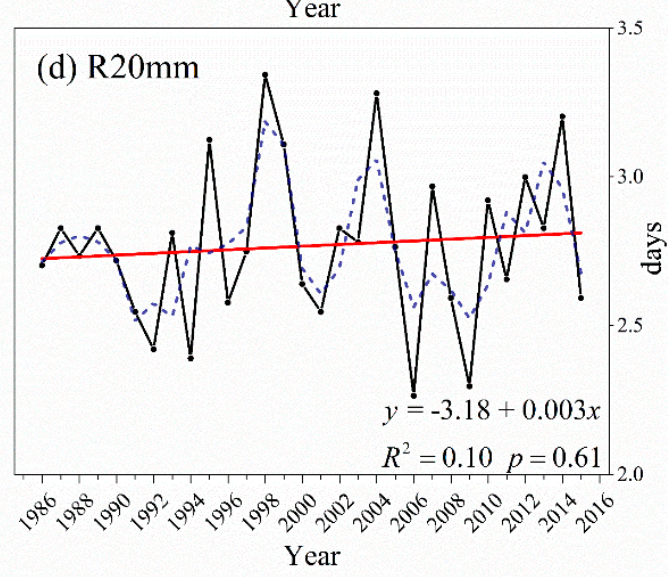

Figure 2. Interannual variation of precipitation days across the Tibetan Plateau from 1986-2015. Graphs represent (a) CDD, (b) CWD, (c) R10mm, and (d) R20mm. The black solid line is the interannual variation, the red solid line is the linear trend, and the blue dotted line is the five-year smoothing average.

\subsubsection{Temporal Trends of Precipitation Totals}

The regional annual series for precipitation totals across the Tibetan Plateau are shown in Figure 3a-f. All the indices demonstrated an increasing trend from 1986 to 2015. PRCPTOT had a weak rising trend at a change rate of $0.583 \mathrm{~mm} /$ year (Figure 3a), SDII had a 0.01 statistically significant increasing trend (at a rate of $0.01 \mathrm{~mm} /$ day/year) (Figure 3b). Over the 1986-2015 period, the regional mean of R95 and R99 had different positive trends with a rate of $0.282 \mathrm{~mm} /$ year and $0.260 \mathrm{~mm} /$ year, respectively; but only the R99 trend passed the significance test at 0.05 significance level (Figure $3 c, d$ ). The magnitude of the slopes for RX1day showed a slightly increase at a rate of $0.053 \mathrm{~mm} /$ year without statistically significance (Figure 3e). The interannual trend of RX5day (at the rate of $0.138 \mathrm{~mm} /$ year) was similar with RX1day, which displayed significant fluctuations (ranged from 63.475 to $48.670 \mathrm{~mm}$ ) in interannual changes, with maximums occurring in the 1999 (Figure 3f). 

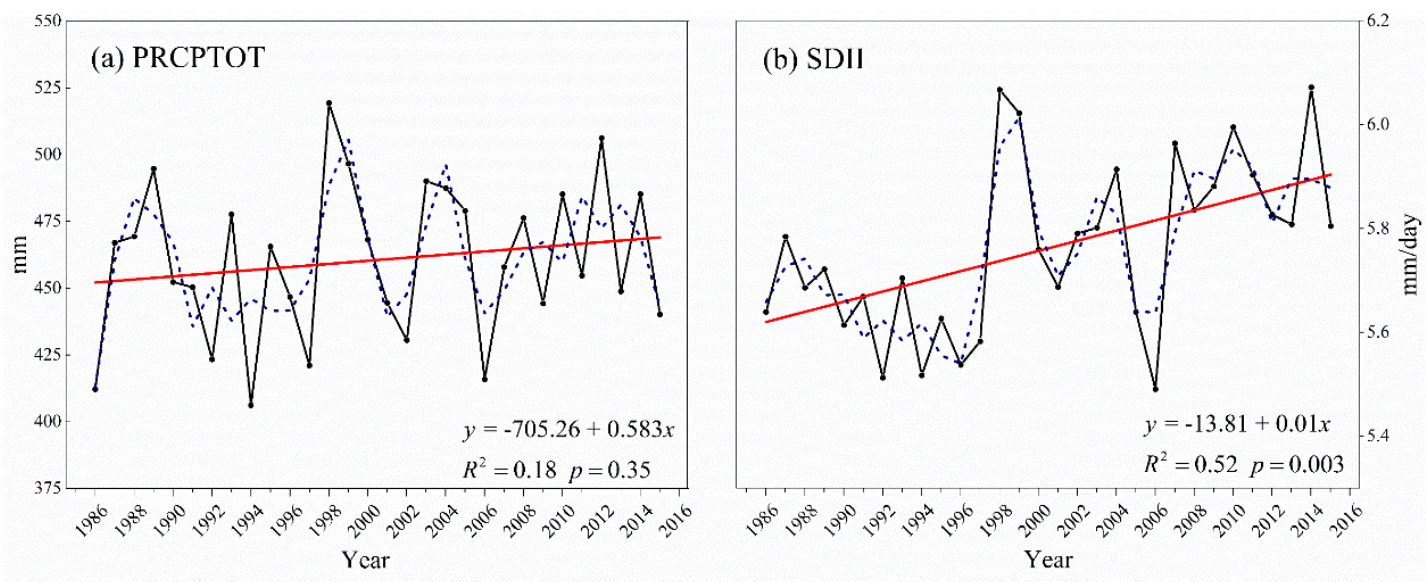

(c) R95
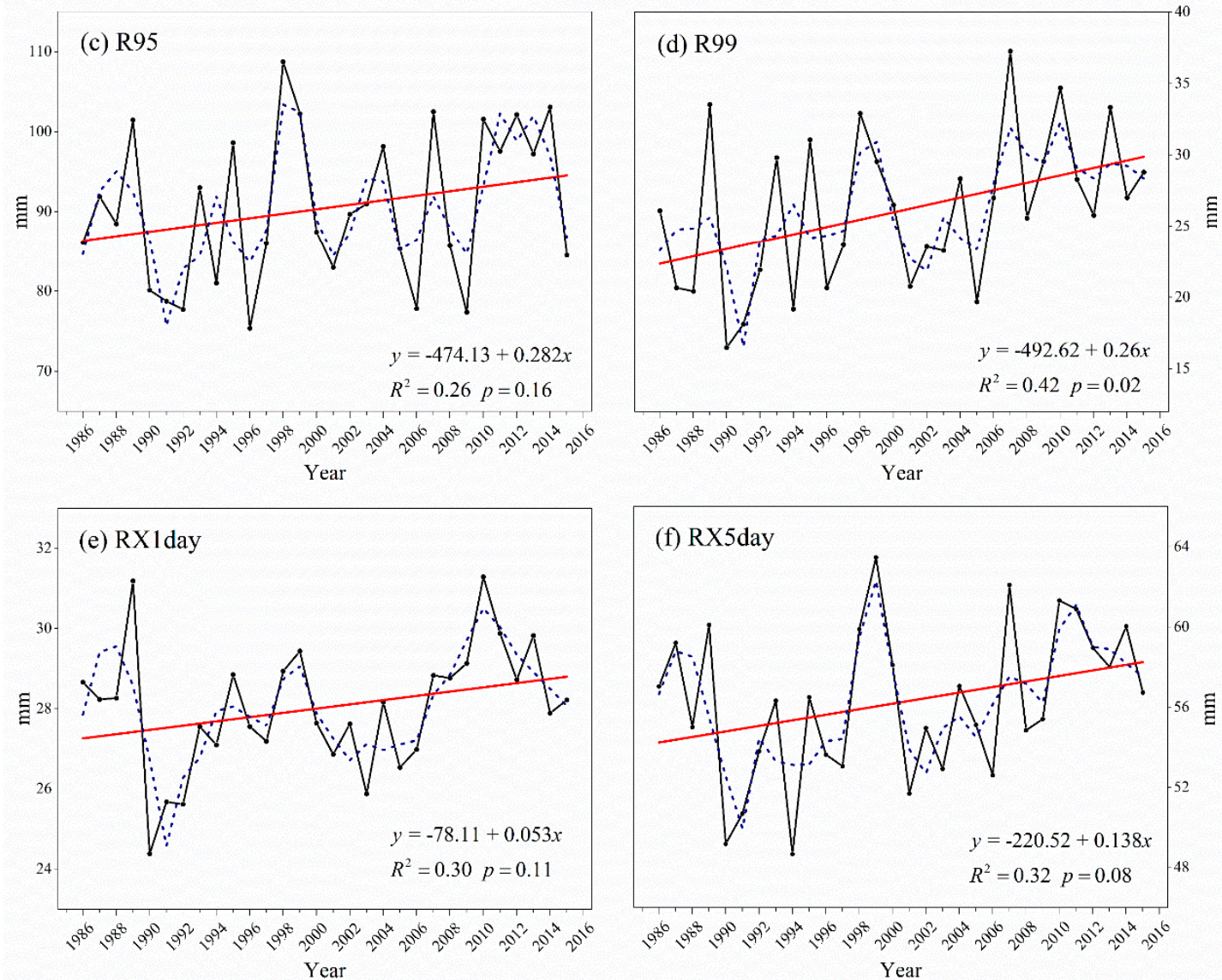

Figure 3. Interannual variation of precipitation across the Tibetan Plateau from 1986-2015. Graphs represent (a) PRCPTOT, (b) SDII, (c) R95, (d) R99, (e) RX1day, and (f) RX5day. The black solid line is interannual variation, the red solid line is the linear trend, and the blue dotted line is the five-year smoothing average.

\subsection{Spatial Pattern of Precipitation Extremes Indices}

\subsubsection{Spatial Pattern of Precipitation Days}

In terms of spatial pattern, the CDD values increased from the north to the southeastern of the Tibetan Plateau, ranging from 223.2 to 38.16 day/year. The CDD value of 49 meteorological stations had upward trends in the study area, but only 8 stations showed significant rising trends, which were mainly distributed in the southeast of the Tibetan Plateau (Figure 4a). The low value of CWD was distributed in the northern plateau, and the high value occurred in the southeastern 
region. In addition, the proportion of stations with increasing trends (44\%) was less than the that with decreasing trends $(56 \%)$, and only the upward trend in Xining station was statistically significant (slope $=0.068$ day/year, $P=0.04$ ) (Figure $4 \mathrm{~b}$ ). The spatial pattern of R10mm showed similarity with R20mm, the values gradually increased from the northwestern to southeastern region of the Tibetan Plateau. Moreover, the R10mm (80\% stations) and R20mm (77\% stations) had increasing trends. The $\mathrm{R} 10 \mathrm{~mm}$ values of 4 stations demonstrated an increasing trend with statistical significance at the 0.05 level. Additionally, the R10mm value of one station displayed a decreasing trend that passed the 0.05 significance test (slope $=-0.018$ day/year, $P=0.02$ ), which was the Chayu Station in Tibet (Figure 4c). The proportion of meteorological stations with rising trends for R20mm accounted for 77\%. Correspondingly, three stations had statistically significant rising trends during 1986-2015 (slope $=0.046$ day/year, 0.018 day/year, 0.119 day/year, respectively). The downward trends were primarily distributed in the southern and northeastern region of the Tibetan Plateau, but no station showing a significant trend (Figure $4 \mathrm{~d}$ ).
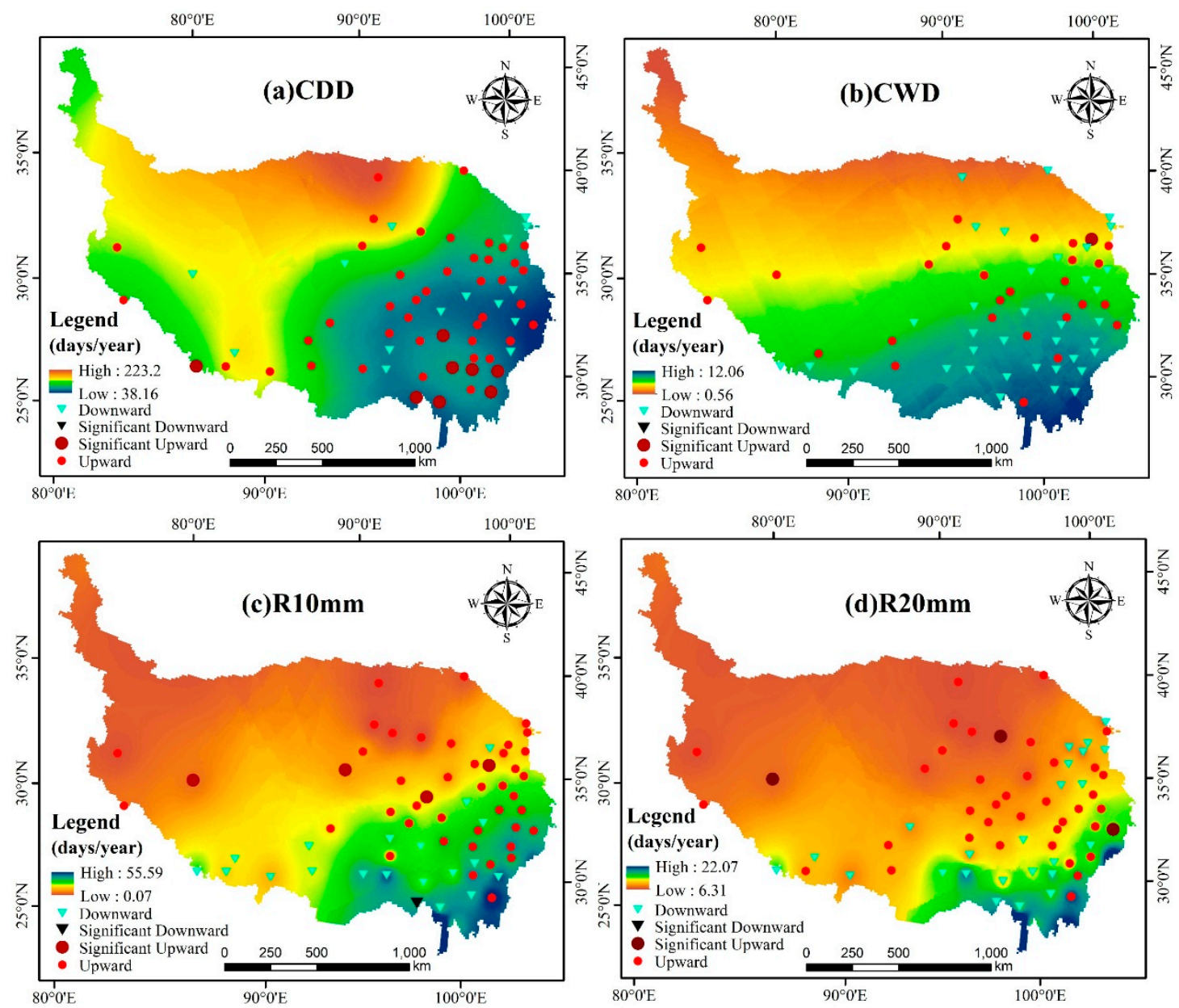

Figure 4. Spatial pattern of values and trends in indices for the number of precipitation days in the Tibetan Plateau from 1986 to 2015 for (a) CDD, (b) CWD, (c) R10mm, and (d) R20mm. The blue triangles represent a downward trend, the black triangles represent a significant downward trend, the red circles represent an upward trend, and the dark red circles represent significant upward trend. A significance level of 0.05 is considered. 


\subsubsection{Spatial pattern of Precipitation Totals}

As shown in Figure 5, a high PRCPTOT value mainly occurred in the southeastern plateau, and a low value was chiefly distributed in the northern and western region of the Tibetan Plateau. The stations with negative trends for PRCPTOT were distributed in the southern region, which covered $34 \%$ of all stations. Moreover, a significant increasing trend of PRCPTOT appeared at stations in Gaize (slope $=2.453 \mathrm{~mm} /$ year, $P=0.007$ ), Tuotuo River (slope $=5.337 \mathrm{~mm} /$ year, $P=0.001$ ), Wudaoliang (slope $=3.548 \mathrm{~mm} /$ year, $P=0.004$ ), and Dari (slope $=3.313 \mathrm{~mm} /$ year, $P=0.012$ ) (Figure 5a). A low SDII value was distributed in the northern region of the Tibetan Plateau, and the high value also was found in the southeastern region. A significant increasing SDII value was observed in region of the southeastern Tibetan Plateau, where two stations demonstrated a significant trend at 0.05 significance level during the study period. Four stations displayed remarkable increasing trends, which distributed in the middle of the plateau. Meanwhile, SDII also showed a nonsignificant decreasing trend at $59 \%$ of the stations (Figure 5b). For RX1day and RX5day, the high value appeared in the eastern, southeastern, and southwestern edges of the Tibetan Plateau, and the low value occurred in the northern edge. More than $37 \%$ of the meteorological stations had rising trends for RX1day. Three stations indicated strong significant changes, and decreasing trends were statistically nonsignificant. The most distinct decreasing region was located in Nielamu (slope $=-1.020 \mathrm{~mm} /$ year) (Figure $5 \mathrm{c}$ ). RX5day exhibited the variation in the research area, with a small range from -0.41 to $0.42 \mathrm{~mm} /$ year. Only $20 \%$ of stations had negative trends, and these stations exhibited uniform distribution, which were mainly distributed in the southern region of the Tibetan Plateau. In addition, five stations located in the west and east of the study region had significant increasing trends (Figure 5d). The spatial pattern of R95 and R99 showed similarities with the high value of RX1day were chiefly distributed in the eastern, southeastern, and southwestern edges of the Tibetan Plateau. For R95, 64\% of the stations had a positive trend; and three stations (Nuomuhong, Dari, Songpan) displayed a significant positive trend (slope $=0.816,2.084,2.248$ $\mathrm{mm}$ /year, respectively) (Figure 5e). As to R99, 47 and 17 stations showed increasing and decreasing trends, respectively; except for four stations with significant increasing trends, all the other stations had nonsignificant trends. Meanwhile, remarkable decreasing trends were observed in the northwest regions, and the eastern area exhibited an upward trend (Figure 5f). Regarding the aforementioned six indices, a high value was observed mainly in the southeastern and the southwestern edges of the Tibetan Plateau, which showed that the southeastern region and the southwestern edge of the Tibetan Plateau were relatively wet regions. The probability of extreme precipitation in the southeastern region was also higher than in other regions. Conversely, the station trends showed that the magnitude and intensity of extreme precipitation increased in the western and northern plateau. Decreasing trends of extreme precipitation were distributed mainly in the southeastern and southwestern region. 

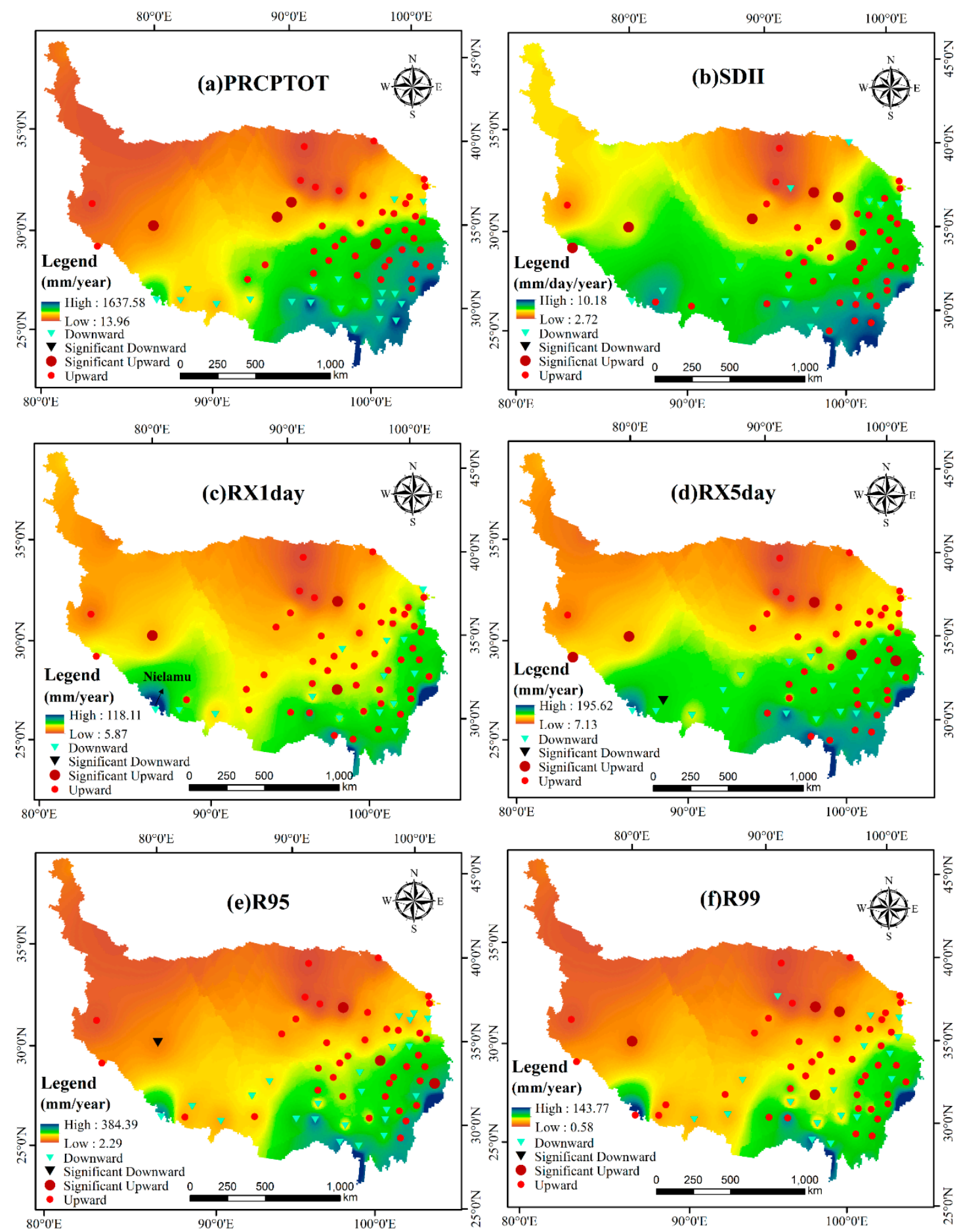

Figure 5. Spatial pattern of values and trends in indices for precipitation in the Tibetan Plateau from 1986 to 2015 for (a) PRCPTOT, (b) SDII, (c) RX1day, (d) RX5day. (e) R95, (f) R99. The blue triangles represent a downward trend, the black triangles represent a significant downward trend, the red circles represent an upward trend, and the dark red circles represent significant upward trend. The significance level of 0.05 was considered.

\subsection{Correlation Coefficients of Precipitation Indices}

To further explore the correlation between extreme precipitation indices and annual average precipitation (AAP), we calculated the correlation coefficients among the extreme precipitation indices (Table 3). The results showed that the most extreme precipitation indices had significant correlations 
with AAP, which had weak correlations with $\operatorname{CDD}(R=-0.06)$, and middle correlation with R99 $(R=0.35)$, and RX1day $(R=0.35)$ both showing a 0.05 significance level. The correlation coefficients between PRCPTOT (and R10mm) and AAP exceeded 0.90 with a 0.01 statistical significance level. Table 3 shows the statistically significant correlations both the extreme precipitation indices. The correlation coefficients between PRCPTOT and R10mm $(R=0.95)$ were statistically significant at a 0.01 level. In particular, in terms of CWD and R20mm, CWD and R95, CWD and R99, CWD and RX1day, CWD and SDII, R10mm and R99, R10mm and RX1day; all of their correlation coefficients were less than 0.30 and were similarly statistically nonsignificant at the 0.05 level.

As shown in Table 4, there are a positive correlation between AAP and each of extreme precipitation indices (except CDD) in forest. The correlation coefficient all passed the significance test at a 0.05 significance level. This demonstrated that extreme precipitation indices can relatively satisfactorily reflect variation in the AAP of a forest. Additionally, AAP was most strongly correlated with R10mm $(R=0.95)$. Furthermore, the correlation coefficients between R10mm and R20mm, R95 and SDII, R99 and RX1day, R99 and RX5day exceeded 0.8 , and their correlations were significant at a 0.01 significance level. In the other three ecosystems, the correlation between AAP and each of the extreme precipitation indices was similar with the result of forest. These results verified that extreme precipitation indices have a relationship with the variation of AAP in three ecosystems (Appendix A Tables A1-A3). Moreover, Appendix A Tables A1-A3 also show statistically significant correlations among most extreme precipitation indices.

Table 3. Correlation coefficients between annual average precipitation (AAP) and the extreme precipitation indices in the Tibetan Plateau.

\begin{tabular}{|c|c|c|c|c|c|c|c|c|c|c|c|}
\hline Indices & AAP & CDD & CWD & PRCPTOT & $\mathrm{R} 10 \mathrm{~mm}$ & R20mm & R95 & R99 & RX1day & RX5day & SDII \\
\hline AAP & 1 & & & & & & & & & & \\
\hline CDD & -0.06 & 1 & & & & & & & & & \\
\hline CWD & $0.52 * *$ & -0.16 & 1 & & & & & & & & \\
\hline PRCPTOT & $0.99 * *$ & -0.05 & $0.51 *$ & 1 & & & & & & & \\
\hline R10mm & $0.94^{* *}$ & 0.01 & $0.43 *$ & $0.95^{* *}$ & 1 & & & & & & \\
\hline $\mathrm{R} 20 \mathrm{~mm}$ & $0.71^{* *}$ & -0.27 & 0.25 & $0.72^{* *}$ & $0.68^{* *}$ & 1 & & & & & \\
\hline R95 & $0.71^{* *}$ & -0.08 & 0.22 & $0.72 * *$ & $0.68^{* *}$ & $0.87^{* *}$ & 1 & & & & \\
\hline R99 & 0.35 * & 0.09 & 0.13 & $0.35^{*}$ & 0.28 & $0.44^{* *}$ & 0.69 ** & 1 & & & \\
\hline RX1day & $0.35^{*}$ & 0.14 & 0.11 & $0.36^{*}$ & 0.26 & $0.35 *$ & $0.64^{* *}$ & $0.78^{* *}$ & 1 & & \\
\hline RX5day & $0.56^{* *}$ & -0.05 & $0.39 *$ & $0.57^{* *}$ & $0.52 * *$ & $0.61^{* *}$ & $0.81^{* *}$ & $0.76^{* *}$ & $0.78^{* *}$ & 1 & \\
\hline SDII & $0.65^{* *}$ & 0.16 & 0.19 & $0.66^{* *}$ & $0.74^{* *}$ & $0.65^{* *}$ & $0.75^{* *}$ & $0.60^{* *}$ & $0.55^{* *}$ & $0.76^{* *}$ & 1 \\
\hline
\end{tabular}

Table 4. Correlation coefficients between annual average precipitation (AAP) and the extreme precipitation indices in the forest.

\begin{tabular}{|c|c|c|c|c|c|c|c|c|c|c|c|}
\hline Indices & AAP & CDD & CWD & PRCPTOT & $\mathrm{R} 10 \mathrm{~mm}$ & $\mathrm{R} 20 \mathrm{~mm}$ & R95 & R99 & RX1day & RX5day & SDII \\
\hline AAP & 1 & & & & & & & & & & \\
\hline CDD & -0.14 & 1 & & & & & & & & & \\
\hline CWD & $0.45^{*}$ & 0.36 & 1 & & & & & & & & \\
\hline PRCPTOT & 1 & -0.14 & 0.45 * & 1 & & & & & & & \\
\hline R10mm & $0.95^{* *}$ & -0.16 & $0.41 *$ & $0.95^{* *}$ & 1 & & & & & & \\
\hline $\mathrm{R} 20 \mathrm{~mm}$ & $0.85^{* *}$ & -0.13 & $0.43 *$ & $0.85^{* *}$ & $0.81 * *$ & 1 & & & & & \\
\hline R95 & 0.83 ** & -0.09 & 0.31 & 0.83 ** & $0.77^{* *}$ & $0.92 * *$ & 1 & & & & \\
\hline R99 & $0.39 *$ & -0.01 & -0.08 & $0.39 *$ & 0.30 & $0.43 *$ & $0.68^{* *}$ & 1 & & & \\
\hline RX1day & 0.37 * & 0.05 & -0.03 & 0.31 & 0.22 & 0.36 & $0.60^{* *}$ & $0.86^{* *}$ & 1 & & \\
\hline RX5day & $0.58^{* *}$ & -0.08 & 0.15 & $0.58^{* *}$ & $0.54^{* *}$ & $0.62 * *$ & $0.79 * *$ & $0.83^{* *}$ & $0.69^{* *}$ & 1 & \\
\hline SDII & $0.76^{* *}$ & -0.06 & 0.29 & $0.77^{* *}$ & $0.84^{* *}$ & $0.75^{* *}$ & $0.81^{* *}$ & $0.52^{* *}$ & $0.47^{* *}$ & $0.68^{* *}$ & 1 \\
\hline
\end{tabular}

Note: ${ }^{* *}$ significant at the 0.01 significance level; ${ }^{*}$ significant at the 0.05 significance level. The table of other three ecosystems are in the Appendix A. 


\subsection{Extreme Precipitation in Different Ecosystems}

Figure 6 and Table 5 show interannual variations in extreme precipitation indices among the different ecosystems in the Tibetan Plateau. The CDD value of desert steppe was the highest (with an average of 206.94 days) of the four ecosystems and showed sharp fluctuations (fluctuating between 118.7 and 317.75 days), which had a rising trend of 0.455 day/year. For CDD in the alpine meadow and the forest, these showed positive trends with 0.625 and 0.454 day/year $(P=0.02$ and 0.03 , respectively), respectively. The CDD value of alpine steppe demonstrated a weak increasing trend ( 0.015 day/year) and had slight fluctuations (Figure 6a and Table 5). However, CWD showed the opposite result, the forest had the highest average value of CWD (11.89 days), and the average value of the other ecosystems decreased with the following order: Alpine meadow, alpine steppe and desert steppe. In addition, only the increasing trends for the alpine steppe were significant at the 0.01confidence level (slope $=0.033$ day/year, $P=0.006$ ) (Figure $6 \mathrm{~b}$ and Table 5). R10mm exhibited nonsignificant variation in the forest, alpine meadow, and desert steppe, however, the index for the alpine steppe displayed an increasing trend (a rate of 0.060 day/year) which passed the significance test at the 0.01 significance level (Figure $6 \mathrm{c}$ and Table 5). The rising trend (with a rate of 0.006 day/year) for R20 $\mathrm{mm}$ in the desert steppe $(P=0.02)$, and the index in the forest and alpine steppe showed weak decreasing trends with rates of 0.018 and 0.001 day/year, respectively. Only the index in the alpine meadow displayed an unclear trend with a rate of 0.016 day/year (Figure $6 \mathrm{~d}$ and Table 5).
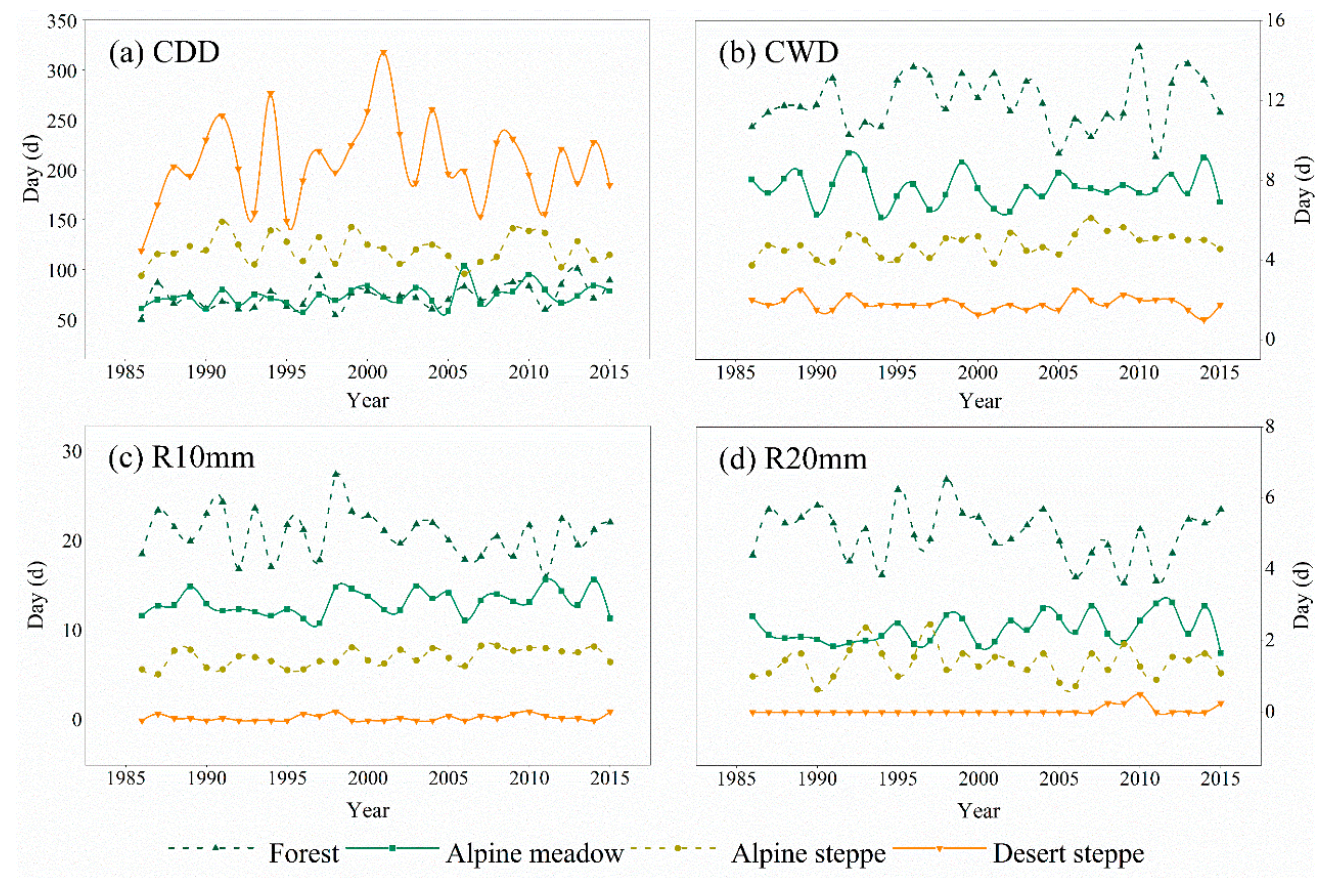

Figure 6. Temporal pattern of precipitation days in different ecosystems of the Tibetan Plateau from 1986 to 2015. Graphs represent (a) annual variation of CDD in different ecosystems, (b) CWD, (c) R10mm, and (d) R20mm.

Table 5. Precipitation days linear trend and significance in different ecosystem.

\begin{tabular}{ccccc}
\hline Index & CDD (day/year) & CWD (day/year) & R10mm (day/year) & R20mm (day/year) \\
\hline Forest & $0.625^{*}$ & 0.015 & -0.049 & -0.018 \\
Alpine meadow & $0.454^{*}$ & -0.001 & 0.05 & 0.016 \\
Alpine steppe & 0.011 & $0.033^{* *}$ & $0.06^{* *}$ & -0.001 \\
Desert steppe & 0.455 & -0.005 & 0.01 & $0.006^{* *}$ \\
\hline
\end{tabular}

Note: ${ }^{* *}$ significant at the 0.01 significance level; * significant at the 0.05 significance level. 
Regarding the PRCPTOT in the four different ecosystems, which showed that these ecosystems could be divided into the following four groups (ordered from high to low for averaged values of PRCPTOT): Forest $(658.96 \mathrm{~mm})$, alpine meadow $(475.66 \mathrm{~mm})$, alpine steppe $(249.53 \mathrm{~mm})$, and desert steppe $(31.45 \mathrm{~mm}$ ) (Figure $7 \mathrm{a}$ and Table 6$)$. The SDII showed that the regional mean of the alpine meadow and alpine steppe were similar (approximately $6.5 \mathrm{~mm} /$ day), the annual trends were positive (slope $=0.01,0.015$ ), and the value in the desert steppe fluctuated obviously (between 2 and $5 \mathrm{~mm} /$ day) (Figure $7 \mathrm{~b}$ and Table 6). The very wet day precipitation (R95) experienced a similar distribution to PRCPTOT, and only the desert alpine had an increasing trend of desert alpine (slope $=0.313 \mathrm{~mm} /$ year, $P=0.02$ ) (Figure 7c and Table 6). R99 in the alpine meadow and the desert steppe changed at a rate of $0.311(P=0.03)$ and $0.192(P=0.02) \mathrm{mm} /$ year, respectively. However, R99 in the forest and the alpine steppe demonstrated that the fluctuation range was remarkable $(67.08-20.62 \mathrm{~mm} / \mathrm{year})$, and their annual trends were increasing at a rate of $0.204 \mathrm{~mm} /$ year (forest) and $0.228 \mathrm{~mm} /$ year (alpine steppe) without passing the statistical significance test (Figure 7d and Table 6). RX1day and RX5day displayed a similar distribution trend to PRCPTOT. Annual trends in alpine steppe and desert steppe were positive, and all passed the 0.05 significance level (Figure 7e,f and Table 6). These results showed that extreme precipitation in the desert steppe and alpine steppe increased significantly. But magnitude of precipitation in the forest decreased, however, and the simple daily precipitation intensity showed nonsignificant increasing trends.
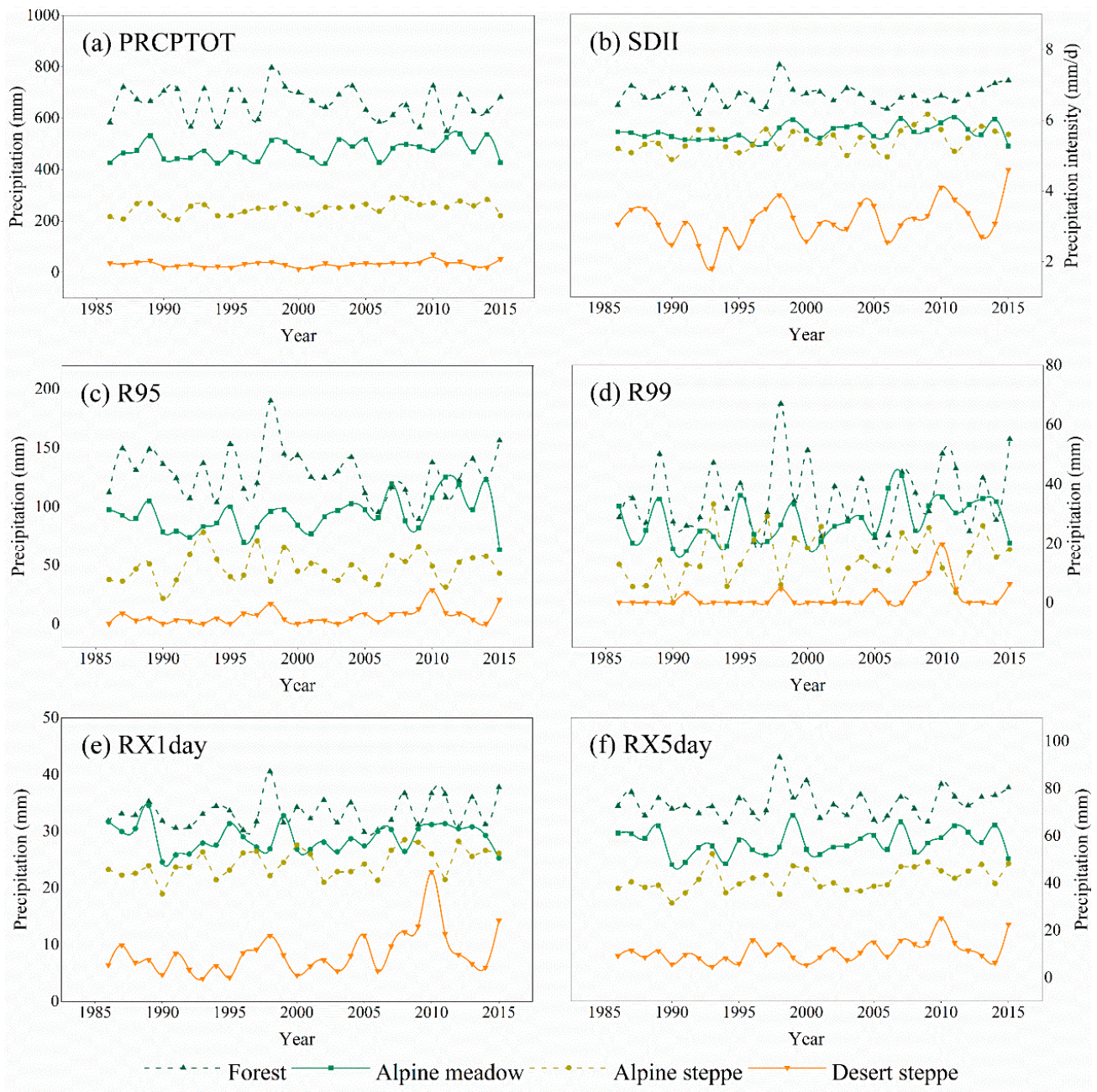

Figure 7. Temporal pattern of precipitation in different ecosystems of the Tibetan Plateau. Graphs represent (a) interannual variation of PRCPTOT, (b) SDII, (c) R95, (d) R99, (e) RX1day, and (f) RX5day. 
Table 6. Precipitation linear trend and significance in different ecosystem.

\begin{tabular}{ccccccc}
\hline Index & $\begin{array}{c}\text { PRCPTOT } \\
\text { (mm/year) }\end{array}$ & $\begin{array}{c}\text { R95 } \\
\text { (mm/year) }\end{array}$ & $\begin{array}{c}\text { R99 } \\
\text { (mm/year) }\end{array}$ & $\begin{array}{c}\text { RX1day } \\
\text { (mm/year) }\end{array}$ & $\begin{array}{c}\text { RX5day } \\
\text { (mm/year) }\end{array}$ & $\begin{array}{c}\text { SDII } \\
\text { (mm/day/year) }\end{array}$ \\
\hline $\begin{array}{c}\text { Forest } \\
\text { Alpine }\end{array}$ & -1.187 & -0.336 & 0.204 & 0.064 & 0.1 & 0.004 \\
meadow & 1.393 & 0.616 & $0.311^{*}$ & 0.002 & 0.103 & $0.01 *$ \\
$\begin{array}{c}\text { Alpine } \\
\text { steppe }\end{array}$ & $1.306^{*}$ & 0.204 & 0.228 & $0.128 *$ & $0.255^{*}$ & $0.015^{*}$ \\
$\begin{array}{c}\text { Desert } \\
\text { steppe }\end{array}$ & 0.283 & $0.313^{*}$ & $0.192 *$ & $0.192 *$ & $0.248^{*}$ & $0.024^{*}$ \\
\hline
\end{tabular}

Note: ${ }^{* *}$ significant at the 0.01 significance level; ${ }^{*}$ significant at the 0.05 significance level.

\subsection{Relationship between Extreme Precipitation and ENSO}

This study analyzed the correlation between extreme precipitation indices and ENSO using the crossover wavelet transform (Figure 8). To synthesize, we selected CWD, R95, SDII, and R20mm, which represented the duration, magnitude, intensity, and frequency of extreme precipitation, respectively. The details for other extreme precipitation indices also are shown in Figure 8.

The crossover wavelet transform between CWD and ENSO showed a statistically significant negative correlation with a 1.5-4.5 year period at the 0.05 confidence level from 1987 to 2001 (Figure 8b), which indicated that the ENSO are closely related to the number of rainy days across the Tibetan Plateau. In addition, Figure $8 \mathrm{c}$ displayed that the ENSO had a significant negative correlation with R95 in the 4-6 year band during 1990-2001 period. The results exhibited that ENSO played an essential part in the magnitude of extreme precipitation across the Tibetan Plateau. The crossover wavelet transform between SDII and ENSO (Figure 8j) demonstrated a significant positive correlation in the 4-6 year period from 1994 to 2002, which implied that ENSO were associated with extreme precipitation intensity. Moreover, Figure 8e illustrated that the ENSO had a statistically significant positive correlation with R20mm across the Tibetan Plateau with a 4-6 year signal at the 0.05 confidence level from 1995 to 2001, which indicated that the ENSO had a prominent association with changes in the frequency of extreme precipitation across the Tibetan Plateau. 


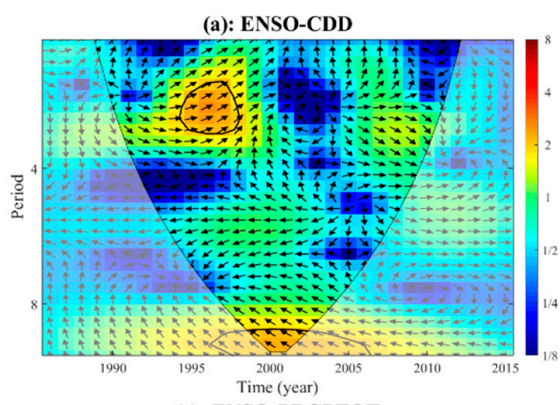

(c): ENSO-PRCPTOT

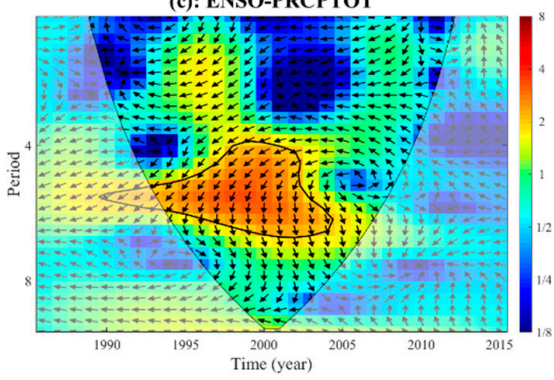

(e): ENSO-R20mm

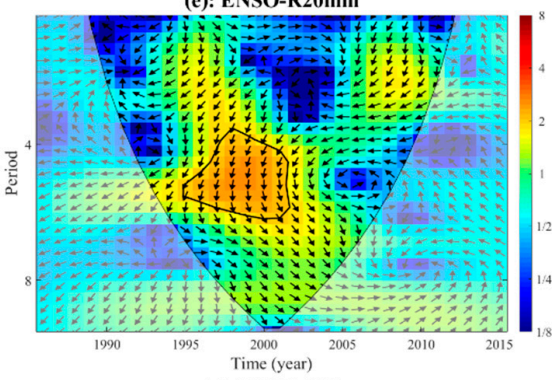

(g): ENSO-R99

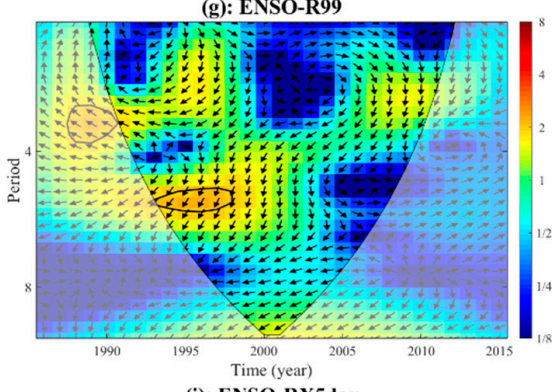

(i): ENSO-RX5day

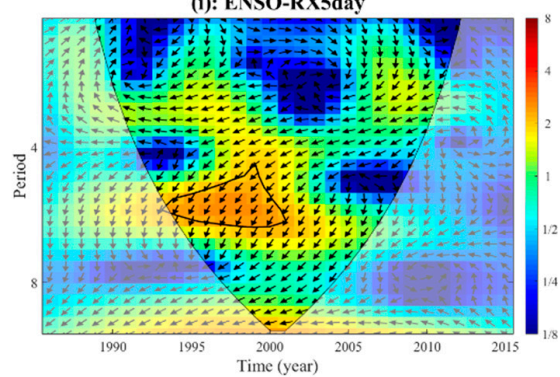

(b): ENSO-CWD

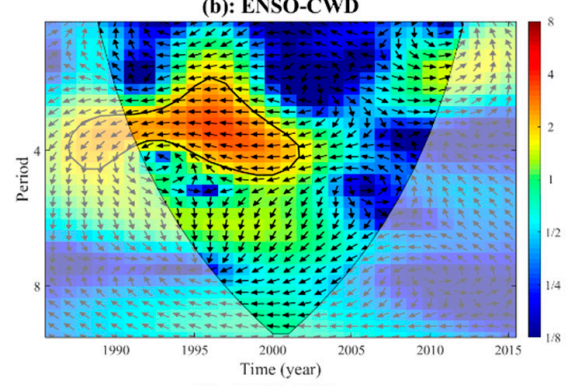

(d): ENSO-R10mm

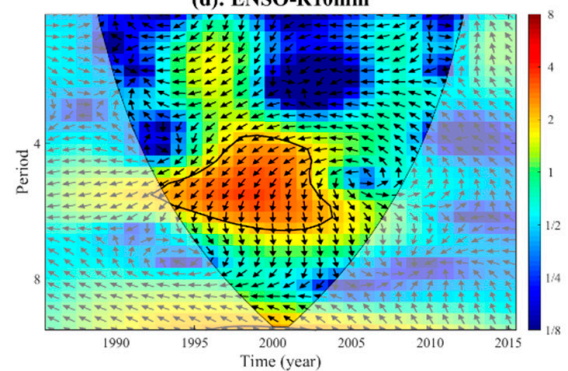

(f): ENSO-R95

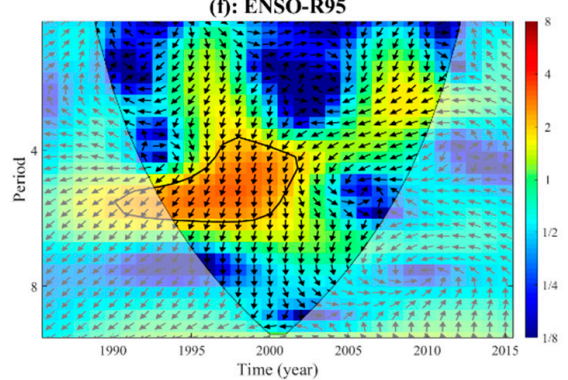

(h): ENSO-RX1day

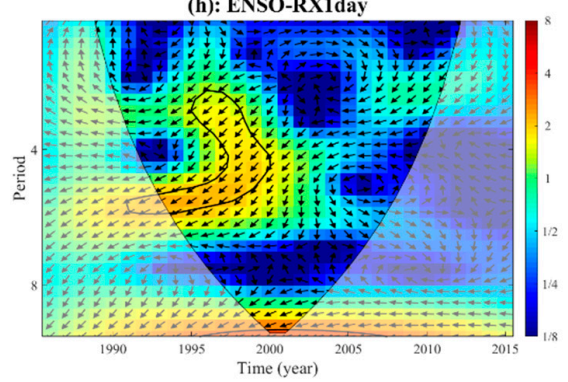

(j): ENSO-SDII

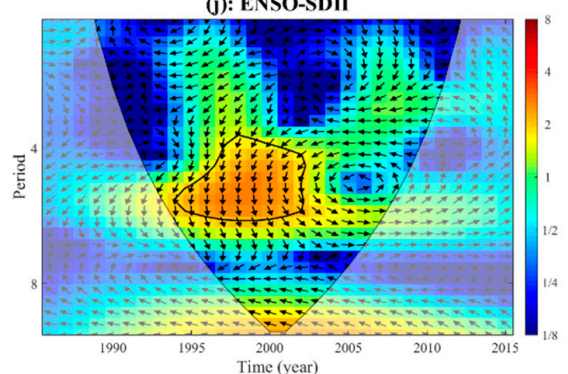

Figure 8. The crossover wavelet transforms between the ENSO and extreme precipitation indices across the Tibetan Plateau. Graphs represent (a) the relationship between CDD and ENSO event, (b) ENSO-CWD, (c) ENSO-PRCPTOT, (d) ENSO-R10mm, (e) ENSO-R20mm, (f) ENSO-R95, (g) ENSO-R99, (h) ENSO-RX1day, (i) ENSO-RX5day, and (j) ENSO-SDII. The thick black contour shows the 0.05 significance level of local power relative to yellow noise. The black line represents the cone of influence where edge influences might distort the picture, which is shown in lighter shades. The direction of the arrow indicates the relative phase relationship, with right-pointing arrows depicting that the two signals are in phase and left-pointing arrows indicating the anti-phase. The color bar on the right represents wavelet energy. 


\section{Discussion}

\subsection{Spatio-Temporal Variability of Extreme Precipitation}

In this study, we analyzed the spatial and temporal patterns of extreme precipitation in the Tibetan Plateau. For spatial distribution, the results illustrated that high-values of extreme precipitation mainly appeared in the southeastern Tibetan Plateau, and the low-values chiefly occurred in the northern and western Tibetan Plateau. The cause may be attributed to the uplift effect of increased relief amplitude on the variation of the airflow, and the uplift of topography caused the precipitation of southeastern plateau which was more than other regions [14]. In addition, increasing trends for extreme precipitation mainly occurred in the western, middle, and northern regions of the Tibetan Plateau, and decreased trends for extreme precipitation was principally located in the southern plateau (Figures 4 and 5). Previous studies found that the South Asia Summer Monsoon (SASM) will mainly affect the precipitation in southeastern of Tibetan Plateau, the decreasing SASM might cause a decreasing precipitation [54]. Extreme precipitation also is associated with the westerlies in the Tibetan Plateau. The westerlies might change the spatial pattern and transportation of moisture across the western and northern region of the Tibetan Plateau under the impact of North Atlantic Oscillation (NAO) activity, and the increased precipitation in these areas were linked to enhanced NAO activity $[55,56]$.

Regarding temporal pattern, the most extreme precipitation indices showed increasing trends in the Tibetan Plateau from 1986 to 2015 (except CWD), and CDD, SDII, and R99 passed 0.05 statistically significance. These results were consistent with previous studies in China, Xinjiang Province and the southwest China (Table 7) [57-59], which also showed similar variations on smaller regional scales (e.g., the western Tibetan Plateau and Three-River Headwaters region [48,60]). These results indicate that extreme precipitation events were more frequent across the Tibetan Plateau. Water cycles may be accelerating with the global warming [61,62], which caused the upward trends of extreme precipitation intensity and frequency $[63,64]$. Extreme precipitation index variations in the southeastern Tibetan Plateau have illustrated different situations, CWD, R20mm, R95, R99, RX1day, and RX5day showed decreasing trends (Table 7). A similar negative trend also occurred in the Loess Plateau [50]. This result indicated that the response of extreme precipitation to climate change may vary from region to region, further highlighting the less spatial consistency of extreme precipitation and the importance of studying extreme precipitation pattern at different region.

Table 7. Temporal variations in the extreme precipitation indices around the Tibetan Plateau from this study and other works.

\begin{tabular}{|c|c|c|c|c|c|c|c|c|}
\hline Index & $\begin{array}{l}\text { Tibetan } \\
\text { Plateau }\end{array}$ & $\begin{array}{c}\text { Western } \\
\text { Tibetan Plateau }\end{array}$ & $\begin{array}{l}\text { Southeastern } \\
\text { Tibetan }\end{array}$ & $\begin{array}{l}\text { Three-River } \\
\text { Headwaters }\end{array}$ & China & $\begin{array}{l}\text { Loess } \\
\text { Plateau }\end{array}$ & $\begin{array}{l}\text { Xinjiang } \\
\text { Province }\end{array}$ & $\begin{array}{l}\text { Southwest } \\
\text { China }\end{array}$ \\
\hline $\begin{array}{c}\text { CDD } \\
\text { (day/year) }\end{array}$ & $0.43 *$ & -0.052 & $0.455^{*}$ & $-0.206^{*}$ & $-0.273 *$ & $-1.865 *$ & -0.002 & -0.124 \\
\hline $\begin{array}{c}\text { CWD } \\
\text { (day/year) }\end{array}$ & -0.006 & 0.017 & -0.035 & -0.016 & $-0.141 *$ & -0.0009 & 0.005 & 0.116 \\
\hline $\begin{array}{l}\text { R10mm } \\
\text { (day/year) }\end{array}$ & 0.023 & -0.006 & 0.046 & 0.016 & 0.004 & -0.003 & $0.02 *$ & 0.013 \\
\hline $\begin{array}{c}\text { R20mm } \\
\text { (day/year) }\end{array}$ & 0.003 & & -0.011 & 0.004 & & 0.0004 & $0.002 *$ & \\
\hline PRCPTOT (mm/year) & 0.583 & 0.047 & 0.495 & $0.833 *$ & 0.113 & $0.187^{*}$ & & -0.42 \\
\hline $\begin{array}{c}\mathrm{R} 95 \\
\text { (mm/year) }\end{array}$ & 0.282 & 0.048 & -0.331 & $0.383 *$ & 0.339 * & -0.059 & $0.628 *$ & 0.674 \\
\hline $\begin{array}{c}\text { R99 } \\
\text { (mm/year) }\end{array}$ & $0.26 *$ & 0.041 & -0.284 & $0.19 *$ & 0.177 * & -0.025 & $0.326^{*}$ & $0.571 *$ \\
\hline $\begin{array}{l}\text { RX1day } \\
\text { (mm/year) }\end{array}$ & 0.053 & 0.036 & -0.049 & -0.016 & $0.05 *$ & -0.022 & $0.079 *$ & 0.036 \\
\hline $\begin{array}{l}\text { RX5day } \\
\text { (mm/year) }\end{array}$ & 0.138 & 0.125 & -0.028 & -0.044 & 0.036 & -0.084 & $0.085 *$ & 0.026 \\
\hline SDII (mm/day/year) & $0.01 *$ & -0.001 & 0.006 & 0.002 & $0.007 *$ & $-0.012 *$ & $0.004 *$ & 0 \\
\hline
\end{tabular}

Note: Data sources and time periods: China during 1961-2013 [58], the western Tibetan Plateau during 1973-2011 [60], and the southeastern Tibetan Plateau during 1960-2011 [12]. Three-River Headwaters during 1960-2012 [48], the Loess Plateau during 1960-2013 [50], the Xinjiang Province during 1960-2009 [59], southwest China during 1951-2010 [57]. * Significant at the 0.05 significance level. 
Some studies found that AAP had a significant correlation with extreme precipitation indices (except for CDD) [43,44], and our study also found similar results in Tibetan Plateau, especially in its four different ecosystems. Therefore, the indices selected in this study were indicative functions of the changes of annual average precipitation [45]. However, CWD had a nonsignificant correlation with most extreme precipitation indices (Tables 3 and 4; Appendix A Tables A1-A3), these results are different with the source region of the Yangtze River [43]. The discrepancy is likely due to the deceasing trends of CWD, and other indices all showed increasing trends across Tibetan Plateau (Figures 3 and 4), but these indies showed different variation in the source region of the Yangtze River [43]. Generally, the discrepancy of data and study period might also cause the different results with previous studies.

\subsection{Characteristics of Extreme Precipitation Indices in Different Ecosystems}

Regarding variations in extreme precipitation in different ecosystems, CDD showed a markedly upward trend in forest areas, but R10mm, R20 mm, and PRCPTOT exhibited downward trends without passing the significance test (Tables 5 and 6). The probable cause of this result is that forests located in the eastern, south and southeast regions of the Tibetan Plateau, the climate of these regions is mainly controlled by the East Asian Summer Monsoon (EASM) and SASM. A decrease in EASM and SASM led to a decline in precipitation from 1975 to 2014 [14]. In addition, one possible cause of the decreasing precipitation and precipitation days is the decreasing trends of evapotranspiration (ET) in southeastern region of the Tibetan Plateau [35]. The alpine steppe and desert steppe are mainly located in areas controlled by the westerly belt. Most of extreme precipitation indices for these ecosystems showed significantly positive trends under the control of enhance NAO activity [55]. Additionally, the elevation of alpine steppe and desert steppe is higher than forest, the increasing trends of most extreme precipitation indices might have been caused by more melting snow and an accelerated hydrological cycle, as more rapid warming occurred at higher elevations than in lower elevations [65]. Comparisons of extreme precipitation indices in different ecosystems have shown that the mean CDD in the forest was lower than that in other regions, but the average value of precipitation was the largest. Moreover, the mean CDD demonstrated a gradually raise for the different ecosystem in the following order: Alpine meadow, alpine steppe and desert steppe. In contrast, the order of decline for the other precipitation indices moved in the opposite direction: Forest, alpine meadow, alpine steppe, and desert steppe (Figures 6 and 7). Previous research verified significant positive correlations between precipitation and evapotranspiration (ET) $[35,65,66]$, and normalized difference vegetation index (NDVI) [67]. Forests are distributed mainly in the western Sichuan Province, southeast Tibetan, and the northern Yunnan Province with deep ravine regions [35]. These areas have lush vegetation, more precipitation, and more ET than other ecosystems across the Tibetan Plateau [68], and as for ET, it has a growth gradient from the southeast to northwest, and it is similar to precipitation (Figure 5). Variations in extreme precipitation are likely to have a detrimental effect on ecosystems and also have a significant influence on the Tibetan Plateau's climate. In this study, spatio-temporal characteristics provided a foundational analysis for future research of the prediction of extreme precipitation in different ecosystems.

\subsection{Impacts of Large-Scale Atmospheric Circulation}

ENSO plays a significant role in global climate change and it is forcefully correlated with extreme precipitation in many regions of the world [69,70]. Figure 8 also confirm that ENSO had a significant negative correlation with a 4-year period in CWD and R95 from 1990 to 2001, but a significant positive correlation with a 4-6 year band between ENSO and R20mm, and SDII during 1995-2001 period in the Tibetan Plateau. Other studies have illustrated a decline in the precipitation of China during ENSO warm phase periods and an increase during the ENSO cold phase [40]. Furthermore, the relationship between the extreme precipitation index and ENSO indicates that in El Niño (La Niña) years, the frequency and magnitude of extreme precipitation events tended to decrease. Surface temperatures of the Tibetan Plateau also indicate a negative ENSO effect occurring in years of extreme 
wetness [24]. In addition, other investigations have found that the North Atlantic Oscillation (NAO) affects extreme precipitation in the western and northern plateau regions, including the Qidam Basin and the Kunlun and Qilian Mountain regions [71]. These studies have illustrated that large-scale atmospheric circulation has a profound impact on extreme precipitation in the study region.

Our previous study analyzed the relationship between precipitation and ET in different ecosystems, but paid no attention to the variation of extreme precipitation across the Tibetan Plateau and in its four different ecosystems. This study had analyzed the temporal and spatial pattern of extreme precipitation in the Tibetan Plateau and its four different ecosystems. It also explored the relationship between extreme precipitation and ENSO. Our study, however, had some drawbacks. Previous study defined a normal climate as being the mean of climatological variables over a 30-year-period [36], but time series was not long enough to identify features of extreme precipitation periodicity in our study. Previous studies considered that there might be some difference between the interpolation result and the actual observation result [72], thus we will explore how to reflect the actual observation data more accurately in the future. Because the response between extreme precipitation and climate change is complex, and considering the characteristic topographical conditions and unique geographical environment in the Tibetan Plateau, the reaction of precipitation to climate change is not clear and requires further research. In the future, the research should consider solar cycles and El Niño in order to reflect the mechanism of extreme precipitation variation.

\section{Conclusions}

In this paper, we examined daily precipitation data from 76 meteorological stations around and within the Tibetan Plateau from 1986 to 2015 . We identified temporal trends and spatial patterns for 10 indices of extreme precipitation and explored trends and determined the magnitude of extreme precipitation for these different ecosystems. We also revealed a correlation between ENSO and extreme precipitation using crossover wavelet transform. The conclusions are summarized as follows: CDD, SDII, and R99 showed significant increased trends across the Tibetan Plateau from 1986 to 2015, but the trends of other extreme precipitation indices were nonsignificant. The spatial pattern revealed the southeastern region of the Tibetan Plateau was the relatively wet region. The higher risk of occurrence of extreme precipitation in the southeastern than that in other regions. In addition, these regions had the upward trends, which were mainly located in the southwestern, middle, and northern part of the Tibetan Plateau. Extreme precipitation exhibited a downward trend in the southeastern plateau. Moreover, variation characteristics of extreme precipitation in different ecosystems showed that R10mm, R20mm, PRCPTOT, and R95 in forest areas had decreasing trends; whereas the other six indices exhibited increasing trends, and only CDD was significant. Meanwhile, extreme precipitation indices generally exhibited increasing trends in the alpine meadow, alpine steppe, and desert steppe. Additionally, CWD and R20mm had slightly decreasing trends in the alpine meadow and the desert steppe, respectively. According to crossover wavelet transform, the duration and magnitude displayed a negative correlation between extreme precipitation and ENSO, but there was a positive correlation between ENSO and the intensity and frequency of extreme precipitation. These results indicate that ENSO are remote drivers of extreme precipitation variability in the Tibetan Plateau, which potentially could improve the ability to predict extreme precipitation in the Tibetan Plateau.

This study provides a foundational analysis for future research of the deeper impact and mechanisms of extreme precipitation and of the impact of extreme precipitation on the Tibetan Plateau ecosystems and its water source.

Author Contributions: Conceptualization, Z.Y. and J.X.; formal analysis, Z.Y.; resources, Z.W.; data curation, Y.Y.; writing-original draft preparation, Z.Y. and J.X.; writing-review and editing, C.Y. and H.Z.; supervision and funding acquisition, W.C. and Y.L.

Funding: This research was funded by the Strategic Priority Research Program of Chinese Academy of Sciences (Grant No. XDA20030302), Open Subject of Big Data Institute of Digital Natural Disaster Monitoring in Fujian (Grant No. NDMBD2018003), National Flash Flood Investigation and Evaluation Project (Grant No. 
SHZH-IWHR-57), China Geological Survey Project (Grant No. DD20190637), Southwest Petroleum University of Science and Technology Innovation Team Projects (Grant No. 2017CXTD09), and the Science and Technology Project of the Xizang Autonomous Region (Grant No. XZ201901-GA-07).

Conflicts of Interest: The authors declare no conflicts of interest.

\section{Appendix A}

Table A1. Correlation coefficients between annual average precipitation (AAP) and the extreme precipitation indices in alpine meadow.

\begin{tabular}{|c|c|c|c|c|c|c|c|c|c|c|c|}
\hline Indices & AAP & CDD & CWD & PRCPTOT & $\mathrm{R} 10 \mathrm{~mm}$ & $\mathrm{R} 20 \mathrm{~mm}$ & R95 & R99 & RX1day & RX5day & SDII \\
\hline AAP & 1 & & & & & & & & & & \\
\hline CDD & 0.02 & 1 & & & & & & & & & \\
\hline CWD & $0.52 * *$ & 0.05 & 1 & & & & & & & & \\
\hline PRCPTOT & $0.99 * *$ & 0.03 & $0.52 * *$ & 1 & & & & & & & \\
\hline R10mm & $0.91^{* *}$ & 0.08 & $0.39 *$ & $0.92 * *$ & 1 & & & & & & \\
\hline $\mathrm{R} 20 \mathrm{~mm}$ & $0.55^{* *}$ & -0.08 & 0.20 & $0.56^{* *}$ & $0.57 * *$ & 1 & & & & & \\
\hline R95 & $0.67^{* * *}$ & 0.13 & 0.27 & $0.68^{* *}$ & $0.67^{* *}$ & $0.89^{* *}$ & 1 & & & & \\
\hline R99 & $0.37^{*}$ & 0.25 & 0.33 & $0.38^{*}$ & 0.29 & $0.60^{* *}$ & $0.69^{* *}$ & 1 & & & \\
\hline RX1day & 0.37 * & 0.11 & 0.34 & 0.37 * & 0.25 & $0.43 *$ & 0.60 ** & $0.74^{* *}$ & 1 & & \\
\hline RX5day & $0.65^{* *}$ & -0.01 & $0.59 * *$ & $0.65^{* *}$ & $0.59 * *$ & $0.69^{* *}$ & $0.77^{* *}$ & 0.70 ** & $0.79 * *$ & 1 & \\
\hline SDII & $0.60 * *$ & 0.24 & 0.24 & $0.62 * *$ & $0.75^{* *}$ & $0.79 * *$ & $0.83^{* *}$ & $0.61^{* *}$ & $0.46^{* *}$ & $0.73 * *$ & 1 \\
\hline
\end{tabular}

Note: ${ }^{* *}$ significant at the 0.01 significance level; ${ }^{*}$ significant at the 0.05 significance level.

Table A2. Correlation coefficients between annual average precipitation (AAP) and the extreme precipitation indices in alpine steppe.

\begin{tabular}{|c|c|c|c|c|c|c|c|c|c|c|c|}
\hline Indices & AAP & CDD & CWD & PRCPTOT & $\mathrm{R} 10 \mathrm{~mm}$ & $\mathrm{R} 20 \mathrm{~mm}$ & R95 & R99 & RX1day & RX5day & SDII \\
\hline AAP & 1 & & & & & & & & & & \\
\hline CDD & -0.13 & 1 & & & & & & & & & \\
\hline CWD & $0.69^{* *}$ & -0.16 & 1 & & & & & & & & \\
\hline PRCPTOT & $0.99 * *$ & -0.12 & $0.69 * *$ & 1 & & & & & & & \\
\hline $\mathrm{R} 10 \mathrm{~mm}$ & $0.88^{* *}$ & 0.14 & $0.62 * *$ & $0.88^{* *}$ & 1 & & & & & & \\
\hline $\mathrm{R} 20 \mathrm{~mm}$ & 0.38 * & 0.16 & 0.21 & $0.39 *$ & 0.36 & 1 & & & & & \\
\hline R95 & $0.50 * *$ & 0.19 & 0.32 & $0.50 * *$ & $0.49 * *$ & $0.92 * *$ & 1 & & & & \\
\hline R99 & 0.28 & 0.07 & 0.15 & 0.27 & 0.15 & $0.67^{* *}$ & $0.75^{* *}$ & 1 & & & \\
\hline RX1day & $0.48^{* *}$ & 0.02 & 0.36 & $0.48^{* *}$ & 0.34 & $0.50^{* *}$ & $0.62 * *$ & $0.78^{* *}$ & 1 & & \\
\hline RX5day & $0.46^{*}$ & 0.05 & $0.58^{* *}$ & $0.45 *$ & $0.41 *$ & $0.48^{* *}$ & $0.66^{* *}$ & $0.70^{* *}$ & $0.74^{* *}$ & 1 & \\
\hline SDII & $0.58^{* *}$ & 0.22 & $0.53^{* *}$ & $0.59 * *$ & $0.63^{* *}$ & $0.67^{* *}$ & $0.82 * *$ & $0.62 * *$ & $0.73^{* *}$ & $0.75^{* *}$ & 1 \\
\hline
\end{tabular}

Note: ${ }^{* *}$ significant at the 0.01 significance level; ${ }^{*}$ significant at the 0.05 significance level.

Table A3. Correlation coefficients between annual average precipitation (AAP) and the extreme precipitation indices in desert steppe.

\begin{tabular}{|c|c|c|c|c|c|c|c|c|c|c|c|}
\hline Indices & AAP & CDD & CWD & PRCPTOT & $\mathrm{R} 10 \mathrm{~mm}$ & $\mathrm{R} 20 \mathrm{~mm}$ & R95 & R99 & RX1day & RX5day & SDII \\
\hline AAP & 1 & & & & & & & & & & \\
\hline CDD & -0.24 & 1 & & & & & & & & & \\
\hline CWD & $0.58^{* *}$ & -0.33 & 1 & & & & & & & & \\
\hline PRCPTOT & $0.99 * *$ & -0.23 & $0.56^{* *}$ & 1 & & & & & & & \\
\hline $\mathrm{R} 10 \mathrm{~mm}$ & $0.67^{* *}$ & -0.25 & 0.22 & $0.69 * *$ & 1 & & & & & & \\
\hline $\mathrm{R} 20 \mathrm{~mm}$ & $0.64^{* *}$ & -0.01 & 0.17 & $0.65^{* *}$ & $0.54^{* *}$ & 1 & & & & & \\
\hline R95 & $0.81 * *$ & -0.11 & 0.28 & $0.82^{* *}$ & $0.89 * *$ & $0.77 * *$ & 1 & & & & \\
\hline R99 & $0.65^{* *}$ & -0.03 & 0.18 & $0.66^{* *}$ & 0.64 ** & $0.92 * *$ & $0.83^{* *}$ & 1 & & & \\
\hline RX1day & $0.78^{* *}$ & -0.10 & 0.22 & $0.80^{* *}$ & $0.81 * *$ & $0.83^{* *}$ & $0.95^{* *}$ & $0.91^{* *}$ & 1 & & \\
\hline RX5day & $0.81^{* *}$ & -0.18 & 0.30 & $0.84^{* *}$ & $0.85^{* *}$ & $0.73^{* *}$ & $0.93^{* *}$ & $0.77^{* *}$ & $0.92^{* *}$ & 1 & \\
\hline SDII & $0.67^{* *}$ & 0.02 & 0.09 & $0.70^{* *}$ & $0.73^{* *}$ & $0.48^{* *}$ & $0.78^{* *}$ & $0.54^{* *}$ & $0.78^{* *}$ & $0.78^{* *}$ & 1 \\
\hline
\end{tabular}

Note: ${ }^{* *}$ significant at the 0.01 significance level; * significant at the 0.05 significance level. 


\section{References}

1. Huntington, T.G. Evidence for intensification of the global water cycle: Review and synthesis. J. Hydrol. 2006, 319, 83-95. [CrossRef]

2. Wu, Z.; Dijkstra, P.; Koch, G.W.; PeÑUelas, J.; Hungate, B.A. Responses of terrestrial ecosystems to temperature and precipitation change: A meta-analysis of experimental manipulation. Glob. Chang. Biol. 2011, 17, 927-942. [CrossRef]

3. Knapp, A.K.; Beier, C.; Briske, D.D. Consequences of More Extreme Precipitation Regimes for Terrestrial. BioScience 2008, 58, 811-821. [CrossRef]

4. Alexander, L.V.; Zhang, X.; Peterson, T.C.; Caesar, J.; Gleason, B.; Klein Tank, A.M.G.; Haylock, M.; Collins, D.; Trewin, B.; Rahimzadeh, F.; et al. Global observed changes in daily climate extremes of temperature and precipitation. J. Geophys. Res. 2006, 111. [CrossRef]

5. Asadieh, B.; Krakauer, N.Y. Global trends in extreme precipitation: Climate models vs. observations. Hydrol. Earth Syst. Sci. Discuss. 2014, 11, 11369-11393. [CrossRef]

6. Donat, M.G.; Alexander, L.V.; Yang, H.; Durre, I.; Vose, R.; Dunn, R.J.H.; Willett, K.M.; Aguilar, E.; Brunet, M.; Caesar, J.; et al. Updated analyses of temperature and precipitation extreme indices since the beginning of the twentieth century: The HadEX2 dataset. J. Geophys. Res. Atmos. 2013, 118, 2098-2118. [CrossRef]

7. Peterson, T.C.; Zhang, X.; Brunet-India, M.; Vázquez-Aguirre, J.L. Changes in North American extremes derived from daily weather data. J. Geophys. Res. 2008, 113. [CrossRef]

8. Aguilar, E.; Aziz Barry, A.; Brunet, M.; Ekang, L.; Fernandes, A.; Massoukina, M.; Mbah, J.; Mhanda, A.; do Nascimento, D.J.; Peterson, T.C.; et al. Changes in temperature and precipitation extremes in western central Africa, Guinea Conakry, and Zimbabwe, 1955-2006. J. Geophys. Res. 2009, 114. [CrossRef]

9. Peng, Y.; Zhao, X.; Wu, D.; Tang, B.; Xu, P.; Du, X.; Wang, H. Spatiotemporal Variability in Extreme Precipitation in China from Observations and Projections. Water 2018, 10, 1089. [CrossRef]

10. Wang, B.; Zhang, M.; Wei, J.; Wang, S.; Li, X.; Li, S.; Zhao, A.; Li, X.; Fan, J. Changes in extreme precipitation over Northeast China, 1960-2011. Quat. Int. 2013, 298, 177-186. [CrossRef]

11. Zhang, Q.; Xu, C.-Y.; Zhang, Z.; Chen, Y.D.; Liu, C.-L.; Lin, H. Spatial and temporal variability of precipitation maxima during 1960-2005 in the Yangtze River basin and possible association with large-scale circulation. J. Hydrol. 2008, 353, 215-227. [CrossRef]

12. Zhang, J.; Shen, X.; Wang, B. Changes in precipitation extremes in Southeastern Tibet, China. Quat. Int. 2015, 380-381, 49-59. [CrossRef]

13. Kang, S.; Xu, Y.; You, Q.; Flügel, W.-A.; Pepin, N.; Yao, T. Review of climate and cryospheric change in the Tibetan Plateau. Environ. Res. Lett. 2010, 5, 015101. [CrossRef]

14. Ge, G.; Shi, Z.; Yang, X.; Hao, Y.; Guo, H.; Kossi, F.; Xin, Z.; Wei, W.; Zhang, Z.; Zhang, X.; et al. Analysis of Precipitation Extremes in the Qinghai-Tibetan Plateau, China: Spatio-Temporal Characteristics and Topography Effects. Atmosphere 2017, 8, 127. [CrossRef]

15. Fowler, H.J.; Wilby, R.L. Detecting changes in seasonal precipitation extremes using regional climate model projections: Implications for managing fluvial flood risk. Water Resour. Res. 2010, 46. [CrossRef]

16. Chuntian, C.; Chau, K.W. Three-person multi-objective conflict decision in reservoir flood control. Eur. J. Oper. Res. 2002, 142, 625-631. [CrossRef]

17. Wang, B.; Bao, Q.; Hoskins, B.; Wu, G.; Liu, Y. Tibetan Plateau warming and precipitation changes in East Asia. Geophys. Res. Lett. 2008, 35. [CrossRef]

18. Huang, M.; Peng, G.; Leslie, L.M.; Shao, X.; Sha, W. Seasonal and regional temperature changes in China over the 50 year period 1951-2000. Meteorol. Atmos. Phys. 2005, 89, 105-115. [CrossRef]

19. Stocker, T.F.; Qin, D.; Plattner, G.-K.; Tignor, M.M.B.; Allen, S.K.; Boschung, J.; Nauels, A.; Xia, Y.; Bex, V.; Midgley, P.M. Summary for Policymakers. In Climate Change 2013: The Physical Science Basis; Contribution of Working Group I to the Fifth Assessment Report of the Intergovernmental Panel on Climate Change; IPCC: Cambridge, UK, 2013.

20. Xu, Z.X.; Gong, T.L.; Li, J.Y. Decadal trend of climate in the Tibetan Plateau-Regional temperature and precipitation. Hydrol. Process. 2008, 22, 3056-3065. [CrossRef]

21. Ding, M.; Zhang, Y.; Liu, L.; Zhang, W.; Wang, Z.; Bai, W. The relationship between NDVI and precipitation on the Tibetan Plateau. J. Geogr. Sci. 2007, 17, 259-268. [CrossRef] 
22. Limsakul, A.; Singhruck, P. Long-term trends and variability of total and extreme precipitation in Thailand. Atmos. Res. 2016, 169, 301-317. [CrossRef]

23. Verdon-Kidd, D.C.; Kiem, A.S. Regime shifts in annual maximum rainfall across Australia-Implications for intensity-frequency-duration (IFD) relationships. Hydrol. Earth Syst. Sci. 2015, 19, 4735-4746. [CrossRef]

24. Bothe, O.; Fraedrich, K.; Zhu, X. The large-scale circulations and summer drought and wetness on the Tibetan plateau. Int. J. Climatol. 2009, 30, 844-855. [CrossRef]

25. Ali, S.; Uijttewaal, W.S.J. Flow resistance of vegetated oblique weir-like obstacles during high water stages. Hydrol. Earth Syst. Sci. 2014, 18, 1-14. [CrossRef]

26. Dong, W.; Lin, Y.; Wright, J.S.; Ming, Y.; Xie, Y.; Wang, B.; Luo, Y.; Huang, W.; Huang, J.; Wang, L.; et al. Summer rainfall over the southwestern Tibetan Plateau controlled by deep convection over the Indian subcontinent. Nat. Commun. 2016, 7, 10925. [CrossRef] [PubMed]

27. Gu, S.; Tang, Y.; Cui, X.; Du, M.; Zhao, L.; Li, Y.; Xu, S.; Zhou, H.; Kato, T.; Qi, P.; et al. Characterizing evapotranspiration over a meadow ecosystem on the Qinghai-Tibetan Plateau. J. Geophys. Res. 2008, 113. [CrossRef]

28. Sun, J.; Qin, X.; Yang, J. The response of vegetation dynamics of the different alpine grassland types to temperature and precipitation on the Tibetan Plateau. Environ. Monit. Assess. 2016, 188, 20. [CrossRef]

29. Yaseen, Z.M.; Sulaiman, S.O.; Deo, R.C.; Chau, K.-W. An enhanced extreme learning machine model for river fl ow forecasting: State-of-the-art, practical applications in water resource engineering area and future research direction. J. Hydrol. 2019, 569, 387-408. [CrossRef]

30. Xu, X.; Lu, C.; Shi, X.; Gao, S. World water tower: An atmospheric perspective. Geophys. Res. Lett. $2008,35$. [CrossRef]

31. Wang, W.-c.; Chau, K.-w.; Qiu, L.; Chen, Y.-b. Improving forecasting accuracy of medium and long-term runoff using artificial neural network based on EEMD decomposition. Environ. Res. 2015, 139, 46-54. [CrossRef]

32. Cui, P.; Jia, Y. Mountain hazards in the Tibetan Plateau: Research status and prospects. Natl. Sci. Rev. 2015, 2, 397-402. [CrossRef]

33. Nowak, A.S.; Nobis, M. Distribution patterns, floristic structure and habitat requirements of the alpine river plant community Stuckenietum amblyphyllae ass. nova (Potametea) in the Pamir Alai Mountains (Tajikistan). Acta Soc. Bot. Pol. 2012, 81, 101-108. [CrossRef]

34. Sun, J.; Cheng, G.; Li, W.; Sha, Y.; Yang, Y. On the Variation of NDVI with the Principal Climatic Elements in the Tibetan Plateau. Remote Sens. 2013, 5, 1894-1911. [CrossRef]

35. Zhang, H.; Sun, J.; Xiong, J. Spatial-Temporal Patterns and Controls of Evapotranspiration across the Tibetan Plateau (2000-2012). Adv. Meteorol. 2017, 2017, 1-12. [CrossRef]

36. WMO. Calculation of Monthly and Annual 30-Year Standard Normals; WMO: Geneva, Switzerland, 1989.

37. Zhang, X.; Yang, F. RClimDex (1.0) User Manual; Climate Research Branch Environment Canada: Ottawa, ON, Canada, 2004.

38. Wang, X.L. Accounting for Autocorrelation in Detecting Mean Shifts in Climate Data Series Using the Penalized Maximal t or F Test. J. Appl. Meteorol. Climatol. 2008, 47, 2423-2444. [CrossRef]

39. Kiem, A.S.; Franks, S.W. On the identification of ENSO-induced rainfall and runoff variability: A comparison of methods and indices. Hydrol. Sci. J. 2001, 46, 715-727. [CrossRef]

40. Ouyang, R.; Liu, W.; Fu, G.; Liu, C.; Hu, L.; Wang, H. Linkages between ENSO/PDO signals and precipitation, streamflow in China during the last 100 years. Hydrol. Earth Syst. Sci. 2014, 11, 3651-3661. [CrossRef]

41. Trenberth, K.E.; Hoar, T.J. El Niño and climate change. Geophys. Res. Lett. 1997, 24, 3057-3060. [CrossRef]

42. Yang, Y.; Fang, J.; Ma, W.; Guo, D.; Mohammat, A. Large-scale pattern of biomass partitioning across China's grasslands. Glob. Ecol. Biogeogr. 2010, 19, 268-277. [CrossRef]

43. Zhou, B.; Liang, C.; Zhao, P.; Dai, Q. Analysis of Precipitation Extremes in the Source Region of the Yangtze River during 1960-2016. Water 2018, 10, 1691. [CrossRef]

44. Zhang, K.; Pan, S.; Cao, L.; Wang, Y.; Zhao, Y.; Zhang, W. Spatial distribution and temporal trends in precipitation extremes over the Hengduan Mountains region, China, from 1961 to 2012. Quat. Int. 2014, 349, 346-356. [CrossRef]

45. Wang, H.; Chen, Y.; Chen, Z. Spatial distribution and temporal trends of mean precipitation and extremes in the arid region, northwest of China, during 1960-2010. Hydrol. Process. 2013, 27, 1807-1818. [CrossRef] 
46. Zhao, Y.; Zou, X.; Cao, L.; Xu, X. Changes in precipitation extremes over the Pearl River Basin, southern China, during 1960-2012. Quat. Int. 2014, 333, 26-39. [CrossRef]

47. Rahimzadeh, F.; Asgari, A.; Fattahi, E. Variability of extreme temperature and precipitation in Iran during recent decades. Int. J. Climatol. 2009, 29, 329-343. [CrossRef]

48. Cao, L.; Pan, S. Changes in precipitation extremes over the "Three-River Headwaters" region, hinterland of the Tibetan Plateau, during 1960-2012. Quat. Int. 2014, 321, 105-115. [CrossRef]

49. Zhang, Y.; Xia, J.; She, D. Spatiotemporal variation and statistical characteristic of extreme precipitation in the middle reaches of the Yellow River Basin during 1960-2013. Theor. Appl. Climatol. 2018, 135, 391-408. [CrossRef]

50. Yan, G.; Qi, F.; Wei, L.; Aigang, L.; Yu, W.; Jing, Y.; Aifang, C.; Yamin, W.; Yubo, S.; Li, L.; et al. Changes of daily climate extremes in Loess Plateau during 1960-2013. Quat. Int. 2015, 371, 5-21. [CrossRef]

51. Liu, S.; Huang, S.; Huang, Q.; Xie, Y.; Leng, G.; Luan, J.; Song, X.; Wei, X.; Li, X. Identification of the non-stationarity of extreme precipitation events and correlations with large-scale ocean-atmospheric circulation patterns: A case study in the Wei River Basin, China. J. Hydrol. 2017, 548, 184-195. [CrossRef]

52. Yang, P.; Xia, J.; Zhang, Y.; Hong, S. Temporal and spatial variations of precipitation in Northwest China during 1960-2013. Atmos. Res. 2017, 183, 283-295. [CrossRef]

53. Torrence, C.; Compo, G.P. A Practical Guide to Wavelet Analysis. Bull. Am. Meteorol. Soc. 1998, 79, 61-78. [CrossRef]

54. Chu, G.; Sun, Q.; Yang, K.; Li, A.; Yu, X.; Xu, T.; Yan, F.; Wang, H.; Liu, M.; Wang, X.; et al. Evidence for decreasing South Asian summer monsoon in the past 160 years from varved sediment in Lake Xinluhai, Tibetan Plateau. J. Geophys. Res. 2011, 116. [CrossRef]

55. Cannon, F.; Carvalho, L.M.; Jones, C.; Bookhagen, B. Multi-annual variations in winter westerly disturbance activity affecting the Himalaya. Clim. Dyn. 2015, 44, 441-455. [CrossRef]

56. Liu, H.; Liu, X.; Dong, B. Intraseasonal variability of winter precipitation over central asia and the western tibetan plateau from 1979 to 2013 and its relationship with the North Atlantic Oscillation. Dyn. Atmos. Oceans 2017, 79, 31-42. [CrossRef]

57. Liu, L.; Xu, Z.X. Regionalization of precipitation and the spatiotemporal distribution of extreme precipitation in southwestern China. Nat. Hazards 2015, 80, 1195-1211. [CrossRef]

58. Wu, X.; Wang, Z.; Zhou, X.; Lai, C.; Lin, W.; Chen, X. Observed changes in precipitation extremes across 11 basins in China during 1961-2013. Int. J. Climatol. 2016, 36, 2866-2885. [CrossRef]

59. Wang, B.; Zhang, M.; Wei, J.; Wang, S.; Li, S.; Ma, Q.; Li, X.; Pan, S. Changes in extreme events of temperature and precipitation over Xinjiang, northwest China, during 1960-2009. Quat. Int. 2013, 298, 141-151. [CrossRef]

60. Wang, S.; Zhang, M.; Wang, B.; Sun, M.; Li, X. Recent changes in daily extremes of temperature and precipitation over the western Tibetan Plateau, 1973-2011. Quat. Int. 2013, 313-314, 110-117. [CrossRef]

61. Durack, P.J.; Wijffels, S.E.; Matear, R.J. Ocean salinities reveal strong global water cycle intensification during 1950 to 2000. Science 2012, 336, 455-458. [CrossRef]

62. Zhai, P.; Zhang, X.; Wan, H.; Pan, X. Trends in Total Precipitation and Frequency of Daily Precipitation Extremes over China. J. Clim. 2005, 18, 1096-1108. [CrossRef]

63. Prein, A.F.; Rasmussen, R.M.; Ikeda, K.; Liu, C.; Clark, M.P.; Holland, G.J. The future intensification of hourly precipitation extremes. Nat. Clim. Chang. 2016, 7, 48-52. [CrossRef]

64. Tian, L.; Yao, T.; Li, Z.; MacClune, K.; Wu, G.; Xu, B.; Li, Y.; Lu, A.; Shen, Y. Recent rapid warming trend revealed from the isotopic record in Muztagata ice core, eastern Pamirs. J. Geophys. Res. 2006, 111. [CrossRef]

65. Ali Ghorbani, M.; Kazempour, R.; Chau, K.-W.; Shamshirband, S.; Taherei Ghazvinei, P. Forecasting pan evaporation with an integrated artificial neural network quantum-behaved particle swarm optimization model: A case study in Talesh, Northern Iran. Eng. Appl. Comput. Fluid Mech. 2018, 12, 724-737. [CrossRef]

66. Moazenzadeh, R.; Mohammadi, B.; Shamshirband, S.; Chau, K.-w. Coupling a firefly algorithm with support vector regression to predict evaporation in northern Iran. Eng. Appl. Comput. Fluid Mech. 2018, 12, 584-597. [CrossRef]

67. Immerzeel, W.W.; Quiroz, R.A.; de Jong, S.M. Understanding precipitation patterns and land use interaction in Tibet using harmonic analysis of SPOT VGT-S10 NDVI time series. Int. J. Remote Sens. 2008, 26, 2281-2296. [CrossRef]

68. Yin, Y.; Wu, S.; Zhao, D.; Zheng, D.; Pan, T. Modeled effects of climate change on actual evapotranspiration in different eco-geographical regions in the Tibetan Plateau. J. Geogr. Sci. 2013, 23, 195-207. [CrossRef] 
69. Sun, X.; Renard, B.; Thyer, M.; Westra, S.; Lang, M. A global analysis of the asymmetric effect of ENSO on extreme precipitation. J. Hydrol. 2015, 530, 51-65. [CrossRef]

70. Jiang, R.; Xie, J.; Zhao, Y.; He, H.; He, G. Spatiotemporal variability of extreme precipitation in Shaanxi province under climate change. Theor. Appl. Climatol. 2016, 130, 831-845. [CrossRef]

71. Liu, H.; Duan, K. Effects of North Atlantic Oscillation on summer precipitation over the Tibetan Plateau. Glaciol. Geocryol. 2012, 2, 311-318.

72. Lovejoy, S.; Schertzer, D.; Ladoy, P. Fractal characterization of inhomogeneous geophysical measuring networks. Nature 1986, 319, 43-44. [CrossRef]

(C) 2019 by the authors. Licensee MDPI, Basel, Switzerland. This article is an open access article distributed under the terms and conditions of the Creative Commons Attribution (CC BY) license (http://creativecommons.org/licenses/by/4.0/). 